INSTITUTO DE PESQUISAS ENERGÉTICAS E NUCLEARES

Autarquia associada à Universidade de São Paulo

\title{
RECUPERAÇÃO DE TÓRIO E TERRAS RARAS VIA PERÓXIDO DO RESÍDUO ORIGINADO NA UNIDADE DE PURIFICAÇÃO DE TÓRIO
}

\author{
ANTÔNIO ALVES DE FREITAS
}

Dissertação apresentada como parte dos requisitos para obtenção do Grau de Mestre em Ciências na Área de Tecnologia Nuclear - Materiais

Orientador:

Dr. Alcídio Abrão

São Paulo

2008 


\section{AGRADECIMENTOS}

Ao Prof. Dr. Alcídio pela amizade, ensinamentos técnicos e humanos, pela paciência, entusiasmo, confiança e pela boa vontade que sempre teve comigo minha eterna gratidão.

À Dra. Fátima pela ajuda e os incentivos e boa vontade para me ajudar.

À Dra. Adir Janete pela amizade pela enorme contribuição esforço e dedicação realização das análises espectrometria gama que nos proporcionou informações para as conclusões deste trabalho.

Às Dras. Cristina, Mitiko e Mari Estela pela ajuda na fase inicial dos experimentos e também sempre pelo incentivo que me deram.

À Dra. Soraya pela amizade e por ter me dado á primeira ajuda fundamental e oportunidade de entrar para a área científica que eu tanto sonhava.

Ao amigo Sergio Rocha por ter me orientado e me ajudado a iniciar a minha carreira profissional juntamente com a sua esposa Dra. Soraya.

As amigas Cristina, Cleide, Augusta, Martinha, pela amizade e por terem me ajudado sempre nos meus trabalhos no IPEN.

Aos amigos Brandão, Edvaldo Vechio, Antônio Roberto, Edivaldo Caetano, David Xavier, Valdelei, Valsir, Miguel, Magela, Ricardo, Renato, João, Takeschi, Pedro, Paulo, Orlando, Alcides, Edson, Varela e outros pela amizade e por tanto que trabalharam na produção do nitrato de tório que gerou 0 RETOTER no IPEN. trabalho.

Ao amigo Coutinho por me incentivar e apoiar na elaboração deste

Ao Dr. Lainetti por tanto incentivo e colaboração neste trabalho.

À Dra. Maria Aparecida Pires por apoiar neste trabalho e com a sua contribuição.

À Dra. Ana Copat pelo incentivo que sempre me forneceu.

À Maria Aparecida Alves pela amizade e incentivo para a conclusão do mestrado.

A todos os amigos e colegas do Centro de Química e Meio Ambiente/IPEN o meu muito obrigado. 
A Deus, Jesus, Maria, Nossa Senhora da Conceição, e São Benedito á quem sempre peço ajuda e orientação. A todos eles o meu eterno agradecimento.

Aos meus pais que são sempre os meus mestres.

À minha irmã Maria Aparecida sempre minha amiga, carinhosa e fiel. Aos meus sobrinhos Andréia e Adriano pelo grande incentivo da minha luta. 


\title{
RECUPERAÇÃO DE TÓRIO E TERRAS RARAS VIA PERÓXIDO DO RESÍDUO ORIGINADO NA UNIDADE DE PURIFICAÇÃO DE TÓRIO
}

\author{
Antônio Alves de Freitas
}

\section{RESUMO}

Como conseqüência da operação de uma unidade de purificação de tório para a produção de nitrato de tório puro, o Instituto de Pesquisas Energéticas e Nucleares (IPEN) armazenou um resíduo rico em terras raras contendo tório e pequeno teor de urânio. Este resíduo é registrado como RETOTER (Resíduo de Tório e Terras Raras). O resíduo contém os radioisótopos naturais das séries do urânio e do tório. Contribuição radioativa significativa é dada pelos descendentes do tório, especialmente o rádio-228 $\left(\mathrm{T}_{1 / 2}=5,7\right.$ anos) comumente conhecido como "mesotório" e o tório-228 ( $\mathrm{T}_{1 / 2}=1,90$ anos). Um descendente do tório de muito interesse e presente com teor razoável é o chumbo-208, um isótopo estável. A partir do encerramento das atividades da planta de purificação de tório, os técnicos do IPEN vêm trabalhando no estabelecimento de tecnologia de aproveitamento do tório, das terras raras e do chumbo-208 contidos no RETOTER. O presente trabalho consiste em dissolver o RETOTER com ácido nítrico separando e confinando os contribuintes radioativos, especialmente o rádio-228, por coprecipitação com sulfato de bário. Em seguida o tório foi separado por precipitação como peróxido. As terras raras presentes no filtrado, foram recuperadas como peróxido de terras raras. 


\title{
RECOVERY OF THORIUM AND RARE EARTHS BY THEIR PEROXIDES PRECIPITATION FROM A RESIDUE PRODUCED IN THE THORIUM PURIFICATION FACILITY
}

\author{
Antônio Alves de Freitas
}

\begin{abstract}
As consequence of the operation of a Thorium purification facility, for pure Thorium Nitrate production, the IPEN (Instituto de Pesquisas Energéticas e Nucleares) has stored away a solid residue called RETOTER (REsíduo de TÓrio e TErras Raras). The RETOTER is rich in Rare-Earth Elements and significant amount of Thorium-232 and minor amount of Uranium. Furthermore it contains several radionuclides from the natural decay series. Significant radioactivity contribution is generated by the Thorium descendents, mainly the Radium-228( $T_{1 / 2}$ $=5.7 \mathrm{y})$, known as mesothorium and Thorium-228( $\left.\mathrm{T}_{1 / 2}=1.90 \mathrm{y}\right)$. An important thorium daughter is the Lead-208, a stable isotope present with an expressive quantity. After the enclosure of the operation of the Thorium purification facility, many researches have been developed for the establishment of methodologies for recovery of Thorium, Rare-Earth Elements and Lead-208 from the RETOTER. This work presents a method for RETOTER decontamination, separating and bordering upon some radioactive isotopes. The residue was digested with nitric acid and the Radium-228 was separated by the Barium Sulphate co-precipitation procedure. Finally, the Thorium was separated by the peroxide precipitation and the Rare-Earth Elements were also recovered by the Rare-Earth peroxide precipitation in the filtrate solution.
\end{abstract}


Página

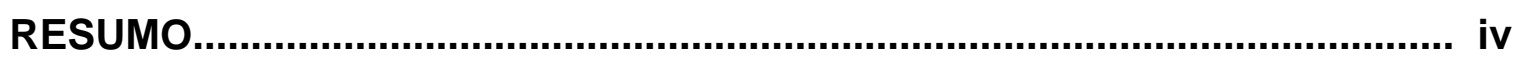

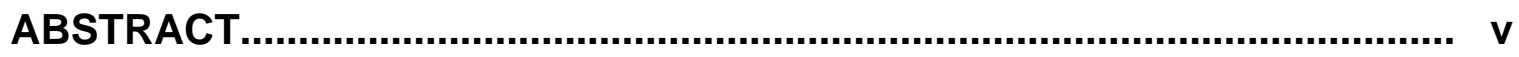

LISTA DE FIGURAS................................................................................. $x$

LISTA DE TABELAS ................................................................................... xii

CAPÍTULO 1 - Introdução, objetivos e considerações gerais 1

1 - Introdução

1.1 - Resíduo de Tório e Terras Raras (RETOTER) 1

1.2 - Objetivo 3

1.3 - Considerações gerais 3

1.3.1 - Tório 3

1.3.1.1 - Aplicações não nucleares do tório 4

1.3.2 - Rádio

1.3.2.1 - Sulfato de rádio $\quad \mathbf{5}$

$\begin{array}{ll}\text { 1.3.2.2 - Aplicações do rádio } & 6\end{array}$

$\begin{array}{ll}\text { 1.3.2.3 - Ação biológica } & 7\end{array}$

$\begin{array}{ll}\text { 1.3.3 - Química geral das terras raras } & 7\end{array}$

1.3.3.1 - Aplicações gerais $\quad 11$

1.3.3.2 - Aplicações biológicas 12

1.3.4 - Processo de extração por solventes do Instituto 12 de Pesquisas Energéticas e Nucleares

$\begin{array}{ll}1.3 .5 \text { - Principais clientes } & 17\end{array}$ 
1.3.6 - Descrição da instalação de fabricação de camisa incandescente para lampião M. Agostini

CAPÍTULO 2 - Parte experimental

2.1 - Equipamentos

2.2 - Reagentes

20

CAPÍTULO 3 - Caracterizações

21

3.1 - Caracterização química do RETOTER

3.2 - Caracterização radioativa do RETOTER

CAPÍTULO 4 - METODOLOGIA

4.4 - Preparação da solução de alimentação para o estudo da separação dos valores do RETOTER

\subsection{1 - Procedimento}

4.5 - Experimentos preliminares para a precipitação do sulfato de bário (rádio)

4.6 - Metodologia estabelecida para a precipitação do sulfato de bário(rádio) 
4.6.1 - Precipitação do sulfato de bário(rádio)

4.6.2 - Filtração do sulfato de bário(rádio)

4.6.3 - Lavagem do precipitado de sulfato bário(rádio)

4.6.4 - Procedimento para dissolução do sulfato de bário(rádio)

4.7 - Precipitação do peróxido de tório

4.7.1 - Filtração do peróxido de tório

4.7.2 - Lavagem do peróxido de tório

4.7.3 - Dissolução do peróxido de tório

4.8 - Experimentos exploratórios de precipitação do carbonato de terras raras

4.8.1 - Filtração do carbonato de terras raras

4.8.2 - Dissolução do carbonato de terras raras

4.9 - Precipitação do peróxido de terras raras

4.9.1 - Filtração do peróxido de terras raras

4.9.2 - Dissolução do peróxido de terras raras

\section{CAPÍTULO 5 - Resultados e Discussão}

5.1 - Resultados da dissolução nítrica do RETOTER

5.2 - Determinação da concentração de Tório e acidez livre

\section{3 - Resíduos}

51

5.4 - Solução estoque de nitrato de tório e terras raras proveniente do RETOTER

5.5 - Resultados dos experimentos de precipitação do sulfato de bário e coprecipitação do rádio 
5.5.1 - Precipitação do sulfato de bário(rádio)

5.5.2 - Resultados obtidos pela metodologia estabelecida para a precipitação do sulfato de bário(rádio)

5.5.3 - Lavagem do precipitado de sulfato de bário(rádio)

5.6 - Precipitação do peróxido de tório 60

5.6.1 - Filtração

61

5.6.2 - Lavagem do peróxido de tório

61

5.7 - Precipitação do carbonato de terras raras

5.7.1 - Filtração

5.7.2 - Dissolução de carbonato úmido de terras

CAPÍTULO 6 - Conclusões

64

REFERÊNCIAS BIBLIOGRÁFICAS 


\section{LISTA DE FIGURAS}

Figura

página

1.3.4.1 - Diagrama de bloco do processo de purificação do 15 nitrato de tório

1.3.4.2 - Unidade de Purificação de Tório

1.3.6 - Esquema das principais etapas do processo de fabricação de camisas incandescentes para lampião

3.1- Fluxograma genérico do sistema de espectrometria gama

3.2 - Série de decaimento natural do ${ }^{238} \mathrm{U}$ (IAEA, 2000)

3.3 - Série de decaimento natural do ${ }^{232}$ Th (IAEA, 2000)

4.1- Diagrama de Bloco do Processo de Separação dos Valores do RETOTER

4.6.1 - Amostras do sulfato de bário(rádio)

4.7 - Amostras de peróxido de tório

4.9.1 - Amostras de precipitados de peróxidos de terras raras

4.9.2 - Amostras das frações obtidas na separação seqüencial dos valores do RETOTER

5.5.1.1 - Espectrometria gama(Nal) da amostra original 1 (nitrato de tório impuro), obtido da dissolução do RETOTER

5.5.1.3 - Espectrometria gama (Nal) do filtrado do sulfato de bário(rádio)

5.5.1.4 - Espectrometria gama (Nal) da água de lavagem do sulfato de bário(rádio)

5.5.1.4 ${ }^{\mathrm{a}}$ - Espectrometria gama (Nal) da água de lavagem 4 a do sulfato de bário(rádio)

5.5.1.5 - Análise do sulfato de bário(rádio) por espectrometria gama com detector de germânio 
5.5.3 - Espectrometria gama do sulfato de bário (rádio)

5.6 - Espectrometria gama do peróxido de tório

61

5.7 - Espectrometria gama do carbonato de terras raras 


\section{LISTA DE TABELAS}

Tabela

página

1.3.3.1 - Cores dos íons $\mathrm{TR}^{3+} \quad 8$

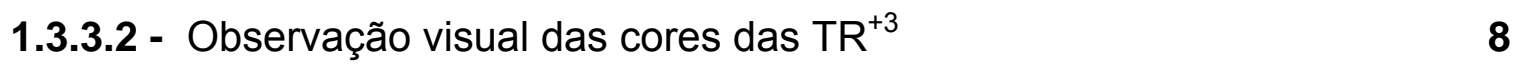

1.3.3.3 - Classificação das terras raras em grupos (sulfatos) 10

3.1.1 - Resultados da análise por espectrometria de fluorescência 22 de Raios-X

3.1.2 - Análise por espectrografia de emissão óptica de elementos menores no RETOTER

3.1.3 - Energias gama e intensidades dos radionuclídeos analisados

4.2.1 - Estudo da variação das relações massa RETOTER/volume e concentração do ácido nítrico

4.2.2 - Relação de massa de (RETOTER/ácido nítrico) 1:5 utilizada nos lotes 02, 03 e 04

4.2.3 - Estudo das filtrações dos resíduos após o tratamento do RETOTER com ácido nítrico em várias concentrações 02,03 e 04

4.7.1 - Massas de peróxido de tório e quantidades de reagentes

4.7.2 - Volumes de soluções de lavagens utilizadas

4.8.1 - Precipitação do peróxido de terras raras

4.8.2 - Massa de peróxido de terras raras em função das massas de reagentes

5.2 - Determinações de acidez livre e das concentrações de tório nas soluções de nitrato bruto obtido pelo tratamento do RETOTER com ácido nítrico

5.3 - Estudo da quantidade de insolúveis nos experimentos de tratamento do RETOTER com ácido nítrico

5.4 - Espectrometria gama (HPGe) do RETOTER 
5.5.3 - Espectrometria gama (HPGe) da fração do $\mathrm{Ba}(\mathrm{Ra}) \mathrm{SO}_{4}$ 59

5.6 - Espectrometria gama (HPGe) da fração peróxido de tório 61

5.7 - Espectrometria gama (HPGe) da fração de carbonato de 63 terras raras 


\section{CAPÍTULO 1}

\section{INTRODUÇÃO, OBJETIVOS E}

\section{CONSIDERAÇÕES GERAIS}

\section{1 - Introdução}

\section{1 - Resíduo de Tório e Terras Raras (RETOTER)}

Nos anos de 1940 deu-se início no Brasil ao processamento das areias monazíticas, tendo em vista a exportação das terras raras, urânio e tório, com os trabalhos de Krumholz e colaboradores ${ }^{[1,2,3]}$. Nesta época, a então Orquima S/A entrou em plena produção de uranato de sódio e carbonato básico de terras raras, comprados pelo governo Federal e de cloretos de TR, para exportação.

Geralmente, os compostos de tório encontrados na natureza não são facilmente dissolvidos em água e não evaporam do solo ou da água para a atmosfera.

As concentrações dos isótopos de tório na água são baixas, geralmente abaixo do limite de detecção do sistema de contagem para espectrometria alfa. Esse fato pode ser explicado pela baixa solubilidade do tório na água que faz com que este elemento fique retido preferencialmente na fase sólida ou na interface sólido-água ${ }^{[4]}$.

No IPEN nos anos de 1970 estabeleceu-se um projeto para a instalação de uma planta de purificação de compostos de tório que se enquadrassem nos padrões de pureza exigidos pela tecnologia nuclear. O método escolhido para purificação foi o de extração por solventes em colunas pulsadas. Na prática esta 
tecnologia deixava uma solução residual, o "refugado", contendo basicamente as terras raras, impurezas metálicas e tório não extraído. Então tratava-se a solução residual com solução de hidróxido de sódio e aquecia-se à temperatura de $90^{\circ} \mathrm{C}$. Este resíduo precipitado foi denominado RETOTER (Resíduo de Tório e Terras Raras).

Tem-se estocado, nos depósitos do IPEN, aproximadamente 25 toneladas de RETOTER. Este resíduo contém quantidade apreciável de tório e terras raras.

A unidade localizava-se no antigo Departamento de Engenharia Química da Diretoria de Materiais do IPEN/CNEN-SP, hoje Centro de Química e Meio Ambiente (CQMA). Sua maior contribuição foi suprir as indústrias nacionais de camisas incandescentes para lampião, atendendo as necessidades da sociedade brasileira e de alguns países. Outras contribuições se deram também na área das pesquisas do ciclo do combustível e de outros setores interessados no uso do tório.

É preocupação deste trabalho contribuir para um processo de separação e aproveitamento do tório e dos elementos do grupo terras raras (TR). Futuramente este material será transferido para outra instalação e, portanto pretende-se definir uma metodologia para o tratamento do resíduo. O RETOTER apresenta certo nível de radioatividade devido ao decaimento do tório e de seus descendentes, sendo a principal contribuição a do rádio-228. Outros radioisótopos descendentes da família do tório, como chumbo-212, bismuto-212 e polônio-210 estão presentes. Faz parte ainda deste trabalho estudar a separação prévia do rádio228 para depois proceder ao trabalho de separação do tório e das terras raras.

O aproveitamento deste material permitirá economia de espaço no estoque. A futura comercialização das terras raras resultantes da separação contribuíra para solucionar problemas de proteção radiológica decorrentes da radioatividade natural associada ao tório e aos seus descendentes.

Encontram-se estudos de diversos métodos para a separação e purificação do tório que utilizam resinas trocadoras de íons; todavia em sua grande maioria 
recomendam a purificação do tório em escala industrial por extração por solvente [5].

Sendo assim, ainda que vários trabalhos já tenham sido conduzidos para a purificação do tório ${ }^{[1,5,7,8,19-25]}$ em diversas situações, foi necessário a busca de novas tecnologias que pudessem ser usadas na otimização do processo para o tratamento do RETOTER. Especialmente para resíduos do tipo RETOTER nada se encontrou na literatura.

\section{2 - Objetivo}

Este trabalho tem como objetivo desenvolver uma metodologia para a recuperação de tório, terras raras e a descontaminação radioativa do rádio contidos no RETOTER, um resíduo originado da produção de nitrato de tório puro. Fez-se o estudo da dissolução do RETOTER com ácido nítrico e a separação do rádio por coprecipitação do sulfato de bário. Estudou-se a separação do tório por meio da precipitação do correspondente peróxido e no filtrado as terras raras foram recuperadas como um grupo, também como peróxido.

\section{3 - Considerações gerais}

\subsection{1 - Tório}

O tório é um elemento químico que ocorre naturalmente na crosta terrestre em teores na faixa 0,01 a 21,5 ppm. É encontrado nas areias monazíticas, nas rochas e em alguns minerais ${ }^{[6]}$. Sabe-se que a monazita é a mais importante fonte de tório e que, juntamente com a Índia, Austrália, China, Madagascar e Estados Unidos, o Brasil possui um dos maiores depósitos de areias monazíticas do mundo $^{[2,6,7]}$.

O tório ocupou um lugar de vanguarda nos anos 70 como combustível nuclear em reatores "breeders" ou regeneradores. Devido à sua propriedade fértil pode ser transformado em urânio-233 a partir de uma reação de captura neutrônica e desintegração beta ${ }^{[2,8]}$, conforme a reação abaixo: 


$$
{ }_{90} \mathrm{Th}^{232}+{ }_{0} \mathrm{n}^{1} \rightarrow{ }_{90} \mathrm{Th}^{233}-\beta \rightarrow{ }_{91} \mathrm{~Pa}^{233}-\beta \rightarrow{ }_{92} \mathrm{U}^{233}
$$

Esta característica permite um aproveitamento mais racional dos combustíveis nucleares, proporcionando uma redução nos custos da energia produzida e aumenta a vida das reservas nucleares de urânio do país ${ }^{[2]}$.

Acredita-se que o tório será elemento de grande interesse quando as reservas mundiais de urânio estiverem esgotadas.

Vários trabalhos foram realizados no Instituto de Pesquisas Energéticas e Nucleares (IPEN) para a recuperação e purificação do tório partindo-se do sulfato de tório cristalizado, hidróxido de tório bruto, nitrato de tório e outros concentrados, onde se separa o tório com elevada pureza na forma de peróxido de tório ${ }^{[9,10,11]}$.

\subsubsection{1 - Aplicações não nucleares do tório}

Entre os usos não nucleares do tório podemos citar: em mantas para lampiões (óxido de tório com óxido de cério e outros compostos); é um elemento de liga para o magnésio, elevando a dureza e resistência em altas temperaturas. É usado para revestir tungstênio em filamentos de válvulas eletrônicas, devido à elevada capacidade de emissão de elétrons. O óxido é usado em cadinhos para altas temperaturas e como catalisador na conversão de amônia para ácido nítrico, no craqueamento do petróleo e na produção de ácido sulfúrico. Vidros com óxido de tório são empregados em lentes para câmaras e instrumentos científicos devido ao alto índice de refração e baixa dispersão ${ }^{[12]}$.

\subsection{2 - Rádio}

Todos os isótopos do rádio decaem para o radônio ou actínio, todos eles são por si radioativos, e todos produzem produtos de decaimento radioativo. 
Conseqüentemente, a determinação radiométrica de um isótopo de rádio deve tomar em conta o rápido crescimento desta série de decaimento ${ }^{[13]}$.

O rádio é um elemento dos metais alcalino-terrosos com propriedades químicas muito similares às do bário. $O$ elemento possui apenas um estado de oxidação (+2) em solução. Por causa desse alto caráter básico, o íon bivalente não é facilmente complexado. Então, muitos compostos de rádio são sais iônicos simples, os quais são brancos quando recentemente preparados, transformandose em amarelo e por último preto devido à idade própria de decomposição pela radiação alfa ${ }^{[13]}$.

Como todos os isótopos do rádio são radioativos e de meia-vida curta em relação ao tempo geológico, todo vestígio de rádio desapareceu há muito tempo. Assim, o elemento só ocorre naturalmente como produto de desintegração nas três séries de desintegração radioativa: do tório, do urânio e do actínio ${ }^{[14]}$.

\subsubsection{1 - Sulfato de rádio}

O sulfato de rádio é o menos solúvel dos sulfatos alcalino-terrosos e provavelmente o composto mais insolúvel de rádio que conhecemos. A sua solubilidade é de $2,1 \times 10^{-4}$ gramas por 100 mililitros em água. Por esta razão a precipitação do sulfato é uma prática comum para a recuperação do rádio, particularmente com adição de carregador de bário. A precipitação é realizada pela adição de ácido sulfúrico diluído na solução de rádio. $O$ sulfato de rádio pode ser desidratado completamente pelo aquecimento ao ar a $300^{\circ} \mathrm{C}$. O composto é solúvel em ácido sulfúrico concentrado, mas precipita em ácido diluído. É convertido para carbonato de rádio por fusão com carbonato de sódio (uma técnica freqüentemente usada para a dissolução do sulfato de bário, porque resulta nos carbonatos de bário(rádio) que são solúveis em alguns ácidos minerais diluídos). Devido à baixa solubilidade do sulfato de rádio é menos perigoso biologicamente que muitos compostos de rádio. Isto é largamente usado na preparação de padrões de rádio ${ }^{[13]}$. 
Então, o sulfato de bário é um bom carregador para o rádio quando coprecipitado de soluções frias, melhor do que de soluções quentes ${ }^{[13]}$.

No trabalho sobre o Estudo da Lixiviação Nítrica de Concentrado Fosfático - tipo apatítico - de Itataia $(\mathrm{CE})^{[15]}$ : A remoção do rádio é possível pela adição de uma solução saturada de nitrato de bário $\left(\mathrm{Ba}\left(\mathrm{NO}_{3}\right)_{2}\right)$ à solução lixiviada, seguida de uma adição, de sulfato de potássio $\left(\mathrm{K}_{2} \mathrm{SO}_{4}\right)$, á fim de precipitar o sulfato de bário-cálcio $\left((\mathrm{Ba}, \mathrm{Ca}) \mathrm{SO}_{4}\right)$. $\mathrm{O}$ comportamento do rádio na rota nítrica é bem mais complexo do que aquele em que o concentrado apatítico é lixiviado com ácido clorídrico $(\mathrm{HCl})$, pois há a cristalização do nitrato de bário $\left(\mathrm{Ba}\left(\mathrm{NO}_{3}\right)_{2}\right)$ o qual não é um eficiente carregador para o rádio, e, portanto, é necessário uma grande adição do íon $\mathrm{Ba}^{+2}$ para uma efetiva remoção do rádio ${ }^{[15]}$.

No trabalho sobre Lixiviação Clorídrica de Concentrado Fosfático: Estudo de Caso ${ }^{[16]}$. O concentrado apatítico do minério de Angico dos Dias (Ba): O ácido clorídrico pode solubilizar as rochas fosfáticas, exceto os minerais silicatos. Seria possível também precipitar o rádio pela adição de uma solução saturada de cloreto de bário $\left(\mathrm{BaCl}_{2}\right)$ à lixívia. Seguida de uma adição de sulfato de sódio $\left(\mathrm{Na}_{2} \mathrm{SO}_{4}\right)$, com o objetivo de precipitar o sulfato de bário $\left(\mathrm{BaSO}_{4}\right)$. Este último composto age como um agente carregador de rádio. Dispondo deste caminho que controla a solução antes de processá-la, há o favorecimento da separação do cálcio e produção do fertilizante fosfato de amônio, via extração por solvente, utilizando o fosfato de tri-n-butila (TBP). O cálcio pode ser precipitado com ácido sulfúrico e, desta forma, o gesso produzido estará livre da radioatividade e o ácido clorídrico poderá ser recuperado ${ }^{[16]}$.

\subsubsection{2 - Aplicações do rádio}

O rádio e os seus descendentes foram usados industrialmente durante a primeira metade do século $X X$, na produção de tintas luminosas. Essas tintas eram luminescentes devido à presença de compostos inorgânicos, que eram excitadas pelas partículas alfa emitidas pelo rádio. A extração do rádio era da uraninita, um minério de urânio que contém traços deste elemento ${ }^{[17]}$. Após a aplicação de diversos tratamentos químicos, obtém-se pequenas quantidades de 
rádio ${ }^{[14] .} \mathrm{O}$ rádio pode ser utilizado como fonte de nêutrons, com largo espectro energético, para reações nucleares. Também se utiliza o elemento em radioterapia, devido à intensa emissão de raios gama por parte dos descendentes. O rádio é uma importante fonte de radônio, o radônio é o gás raro mais pesado ${ }^{[17]}$.

O rádio é utilizado na ionização de gases como o oxigênio para se obter ozônio. Era empregado na produção de materiais fluorescentes para painéis e mostradores de relógio, até que se descobriu que a exposição ao elemento provoca sérios danos à saúde. Em sua presença, é preciso utilizar materiais protetores que bloqueiam a passagem da radiação ${ }^{[14]}$.

O sulfato de rádio $\left(\mathrm{RaSO}_{4}\right)$ já foi muito usado no tratamento de câncer, graças a sua radiação gama que destrói o tecido maligno.Em muitas aplicações terapêuticas, no entanto, o rádio foi substituído por isótopos artificiais como o cobalto-60 e césio-137, mais eficazes e menos dispendiosos ${ }^{[14]}$.

\subsubsection{3 - Ação biológica}

O rádio é bastante tóxico devido à sua radioatividade. A quantidade máxima de rádio permitida no corpo humano é da ordem de 0,1 microgramas. Devido à semelhança das suas propriedades químicas com as do cálcio, o rádio tende a acumular-se nos ossos prejudicando o correto desenvolvimento dos glóbulos vermelhos produzidos na medula óssea. Em casos extremos pode causar o cancro dos ossos ${ }^{[17]}$.

\subsection{3 - Química geral das terras raras ${ }^{[6]}$}

Vários dos lantanídeos se apresentam como íons coloridos. $\mathrm{O}$ aparecimento da cor é devido às transições fff. Interessante é observar que a seqüência das cores se repete em duas séries, La a Gd e Lu a Gd, como mostra a TAB. 1.3.3.1, e, como conseqüência das transições f-f, virtualmente as cores são independentes do ambiente dos íons ${ }^{[6]}$. 
Importante destaque no comportamento espectroscópico das terras raras (TR) é a existência dos fenômenos de luminescência de certos íons, especialmente Eu, quando usados como ativadores em óxidos, silicatos e outros "fósforos". Fósforos dopados com $\mathrm{Eu}^{+3}$ são usados em tubos de TV.

TABELA 1.3.3.1 - Cores dos íons $\mathrm{TR}^{3+[6]}$.

\begin{tabular}{cccc}
\hline Íons & Cor & ĺons & Cor \\
\hline $\mathrm{La}$ & Incolor & $\mathrm{Lu}$ & Incolor \\
$\mathrm{Ce}$ & Incolor & $\mathrm{Yb}$ & Incolor \\
$\mathrm{Pr}$ & Verde & $\mathrm{Tm}$ & Verde \\
$\mathrm{Nd}$ & Lilás & $\mathrm{Er}$ & Lilás \\
$\mathrm{Pm}$ & Róseo, amarelo & $\mathrm{Ho}$ & Róseo, amarelo \\
$\mathrm{Sm}$ & Amarelo & $\mathrm{Dy}$ & Amarelo \\
$\mathrm{Eu}$ & Róseo claro & $\mathrm{Tb}$ & Róseo claro \\
$\mathrm{Gd}$ & Incolor & $\mathrm{Gd}$ & Incolor \\
\hline
\end{tabular}

As cores das terras raras, apresentadas como observação por visão direta, sempre apresentam algumas diferenças, variando de autor para autor. $\mathrm{Na}$ TAB. 1.3.3.2 estão indicadas as cores em função dos estados de valência, em solução.

TABELA 1.3.3.2 - Observação visual das cores das $\mathrm{TR}^{3+}{ }^{[6]}$.

\begin{tabular}{cccc}
\hline İons & Cor & Íons & Cor \\
\hline La - III & Incolor & Tb - III & Levemente \\
& & róseo \\
$\mathrm{Ce}-\mathrm{III}$ & Incolor & $\mathrm{Dy}-\mathrm{III}$ & Amarelo \\
$\mathrm{Ce}-\mathrm{IV}$ & Vermelho, laranja & $\mathrm{Ho}-\mathrm{III}$ & Amarelo \\
$\mathrm{Pr}-\mathrm{III}$ & Verde & $\mathrm{Er}-\mathrm{III}$ & Avermelhado \\
$\mathrm{Nd}-\mathrm{III}$ & Avermelhado & $\mathrm{Tm}-\mathrm{III}$ & Verde \\
$\mathrm{Sm}-\mathrm{III}$ & Avermelhado & $\mathrm{Yb}-$ III & Incolor \\
$\mathrm{Sm}-\mathrm{II}$ & Avermelhado & $\mathrm{Lu}-\mathrm{III}$ & Incolor \\
$\mathrm{Eu}-\mathrm{II}$ & Amarelo pálido & $\mathrm{Y}-\mathrm{III}$ & Incolor \\
$\mathrm{Eu}-\mathrm{III}$ & Levemente róseo & & \\
$\mathrm{Gd}-\mathrm{III}$ & Incolor & & \\
\hline
\end{tabular}

A química das $\mathrm{TR}^{3+}$ é predominantemente iônica e determinada principalmente pelo tamanho de seus cátions trivalentes. 
O estado trivalente é característico para todas as terras raras. Elas formam óxidos do tipo $\mathrm{TR}_{2} \mathrm{O}_{3}$ com exceção o $\mathrm{Pr}_{4} \mathrm{O}_{11}$ e o $\mathrm{TB}_{4} \mathrm{O}_{7}$, parecidos com os óxidos dos elementos alcalino-terrosos, como $\mathrm{CaO}$ e $\mathrm{BaO}$, absorvem dióxido de carbono e água do ar para formar os correspondentes carbonatos e hidróxidos, respectivamente ${ }^{[6]}$.

Os carbonatos das TR são sais pouco solúveis em água e têm papel importante na tecnologia das terras raras. Dos carbonatos, um grande número é de carbonatos básicos. Os carbonatos normais são mais facilmente obtidos pela hidrólise dos cloracetatos:

$2 \mathrm{TR}\left(\mathrm{C}_{2} \mathrm{Cl}_{3} \mathrm{O}_{2}\right)_{3}+(\mathrm{X}+3) \mathrm{H}_{2} \mathrm{O} \longrightarrow \mathrm{TR}_{2}\left(\mathrm{CO}_{3}\right)_{3} \times \mathrm{H}_{2} \mathrm{O}+3 \mathrm{CO}_{2}+6 \mathrm{CHCl}_{3}$

Os carbonatos apresentam água de hidratação, por exemplo, $\mathrm{La}_{2}\left(\mathrm{CO}_{3}\right)_{3} \cdot 8 \mathrm{H}_{2} \mathrm{O}{ }^{[6]}$.

Um carbonato bem caracterizado é o $\mathrm{La}_{2}\left(\mathrm{CO}_{3}\right)_{3} .8 \mathrm{H}_{2} \mathrm{O}$, cuja estrutura é algo complexa, apresentado o La número de coordenação 10 , e o ânion carbonato pode atuar como ligante uni e bidentado nesta estrutura.

A química dos carbonatos na tecnologia das TR é importante, tanto para precipitar como para solubilizá-las. Os carbonatos das TR formam com os carbonatos alcalinos sais complexos mais solúveis que os carbonatos normais.

A adição de hidrogenocarbonato de sódio a uma solução de TR, e acerto do $\mathrm{pH}$ a $5-6$, produz um precipitado gelatinoso de carbonato de TR. Com o envelhecimento o sal se torna cristalino. A composição corresponde ao carbonato normal $\mathrm{TR}_{2}\left(\mathrm{CO}_{3}\right)_{3} \cdot \mathrm{xH}_{2} \mathrm{O}$. A precipitação com carbonato de sódio também leva ao carbonato normal, mas uma vez que o pH é mais alto, algum carbonato básico pode se formar. Por fervura da suspensão dos carbonatos de TR resulta a hidrólise com eliminação de $\mathrm{CO}_{2}$, e a composição se aproxima de $\operatorname{TR}(\mathrm{OH}) \mathrm{CO}_{3}$. O uso de excesso de carbonato ou precipitação pela adição da solução de TR ao carbonato de sódio (ou outro carbonato alcalino) resulta na formação de carbonatos duplos, como por exemplo, 
$2 \mathrm{La}_{2}\left(\mathrm{CO}_{3}\right)_{3} \cdot 3 \mathrm{Na}_{2} \mathrm{CO}_{3} \cdot 2 \mathrm{OH}_{2} \mathrm{O}, \mathrm{La}_{2}\left(\mathrm{CO}_{3}\right)_{3} \cdot \mathrm{K}_{2} \mathrm{CO}_{3} \cdot 12 \mathrm{H}_{2} \mathrm{O}$, e La $\left(\mathrm{CO}_{3}\right)_{3} \cdot\left(\mathrm{NH}_{4}\right)_{2} \mathrm{CO}_{3} \cdot 4 \mathrm{H}_{2} \mathrm{O}$, sendo que muitos destes compostos ainda não foram bem caracterizados. Tanto os carbonatos simples como os carbonatos duplos têm considerável grau de solubilidade em carbonato de potássio, provavelmente devido à formação de complexos.

Um bom procedimento para a preparação dos carbonatos de TR é pela hidrólise dos correspondentes tricloroacetatos. A seguir, principais fatores que influenciam a preparação ${ }^{[6]}$ :
a) natureza do precipitante;
b) temperatura e pressão;
c) concentração do cátion e do precipitante e
d) período de envelhecimento ${ }^{[6]}$.

Subdivisão em grupos ${ }^{[6]}$

É uma prática de muitos anos classificarem-se as terras raras em grupos. Uma sistemática adotada é apresentada na (TAB. 1.3.3.3).

TABELA 1.3.3.3 - Classificação das terras raras em grupos (sulfatos).

\begin{tabular}{ccc}
\hline Grupo do cério & Grupo do térbio & Grupo do ítrio \\
\hline $\mathrm{La}$ & $\mathrm{Eu}$ & $\mathrm{Dy}$ \\
$\mathrm{Ce}$ & $\mathrm{Gd}$ & $\mathrm{Ho}$ \\
$\mathrm{Pr}$ & $\mathrm{Tb}$ & $\mathrm{Yr}$ \\
$\mathrm{Nd}$ & & $\mathrm{Er}$ \\
$\mathrm{Sm}$ & & $\mathrm{Yb}$ \\
& & $\mathrm{Lu}$ \\
Insolúveis & Pouco solúveis & Solúveis \\
\hline
\end{tabular}

Esta classificação foi estabelecida de acordo com a solubilidade dos sulfatos duplos de Na e K com as TR: Grupo do Cério, pouco solúvel, Grupo do Ítrio, solúvel e Grupo do Térbio ocupando uma posição intermediária. Interessante observar que há uma ordem segundo os números atômicos.

Outros autores preferem a classificação em apenas dois grupos - Grupo do Cério (La a Sm) e Grupo do ítrio (Eu a Lu). 


\subsubsection{1 - Aplicações gerais ${ }^{[6]}$}

Vê-se assim que as TR ocupam papel importante na pesquisa, abrangendo campos como biologia, química (estado sólido e solução), geologia, metalurgia, ciência dos materiais, medicina, ciências nucleares, física (magnestimo e supercondutividade) e vários ramos de espectroscopia.

Até 1972 o maior consumo era para as terras raras não separadas, em grupos. Apenas cerca de $1 \%$ deste total era usado como terras raras individuais. O consumo era distribuído assim:

- Catalisadores para petróleo: $30 \%$ ( catalisador tipo zeólito, aumentando a eficiência catalítica de um fator 3 );

- Polimento de vidros: 19\% (lentes, vidro plano, tubo de TV, pedras preciosas, transistores wafers);

- Aços: $17 \%$ ( redução do teor de S e modificação da morfologia do particulado de sulfeto para melhoria da força de ruptura transversa);

- Ferro dúctil 14\% ( para melhorar a morfologia da partícula de carbono e aumentar a ductilidade );

- Descoloração de vidros: 8\% ( remove a cor verde do vidro flint, reduz o consumo de selênio usado então e elimina o uso de arsênio );

- Arcos voltálicos de carbono: $5 \%$ ( produz luz idêntica à luz solar e aumenta a intensidade da luz por um fator 10 );

- Aditivos em vidros: $3 \%$ ( cria cor variando do amarelo ao violeta, modifica as propriedades de absorção da luz e aumenta o índice de refração para lentes e fibras ópticas);

- Pedras de isqueiros: $2 \%$ ( um dos usos mais antigos );

- Miscelânia: 2\% ( cerâmicas, metalurgia, química, eletrônica etc.).

O uso de terras raras individuais tem o seguinte espectro:

Fósforos: TV (Eu e Y), dispositivos ópticos, raios-X, lasers (vidros de Nd, garnets de Nd e Y-AL);

Ímãs permanentes $\left(\mathrm{SmCo}_{5}\right)$ para relógios, motores, tubos de microondas, transporte e memória de computadores; 
Uso nuclear: barras de controle (Eu e Dy), venenos queimáveis ( $\mathrm{Sm}$ e Gd), segurança em reatores (Sm e Gd);

Superligas (altas temperaturas e resistência à corrosão): La, Ce e Y;

Eletrônica: garnets Y-Al e

Outros usos: cerâmicas para alta temperatura, lubrificantes, sondas biológicas e pesquisas.

\subsubsection{2 - Aplicações Biológicas ${ }^{[18]}$}

O interesse em aplicar as terras raras na investigação das propriedades e funções de sistemas bioquímicos e na determinação de substâncias biologicamente ativas tem aumentado. As terras raras são usadas principalmente como sondas espectroscópicas no estudo de biomoléculas e suas funções, por exemplo, em traçadores biológicos para acompanhar o caminho percorrido pelos medicamentos no homem e em animais; como marcadores em imunologia (fluoroimunoensaios) e também, como agentes de contraste em diagnóstico não invasivo de patologias em tecidos por imagem de RMN (ressonância magnética nuclear).

\subsection{4 - Processo de Extração por Solventes do Instituto de Pesquisas Energéticas e Nucleares.}

No Brasil, no próprio local da jazida, a areia monazítica era concentrada em até 95\% por lavagem, separação magnética, e processos eletrostáticos antes de ser transportada para outros locais. Na antiga APM - Administração da Produção da Monazita, depois Nuclemon, uma subsidiária da antiga Nuclebrás, recebia-se o concentrado de monazita e realizava-se o enriquecimento por meio de mesas vibrantes, separadores magnéticos, obtendo-se a monazita com teores de até 99\%. Após o tratamento químico, obtinham-se o fosfato trissódico, o cloreto de terras raras, o sulfato de tório, o oxicarbontao de tório, o diuranato de sódio e outros $^{[7]}$. 
Na unidade do IPEN ${ }^{[5]}$ recebia-se o sulfato de tório cristalizado proveniente da Nuclemon. Esse produto era primeiro transformado em oxicarbonato de tório, seguido de lavagem com água quente para a eliminação completa do íon sulfato, após o tratamento filtrava-se a vácuo. Estas operações eram feitas em bateladas de 50 quilos de sulfato de tório. Obtido o oxicarbonato de tório (OCTO), então se dissolvia com ácido nítrico concentrado e digeria-se a uma temperatura de $90^{\circ} \mathrm{C}$ durante uma hora. Depois se fazia a filtração a vácuo. A solução de nitrato de tório, então passava por um controle analítico, para saber a acidez livre, a concentração de tório, a concentração de terras raras e também as das impurezas. Fazia-se em seguida o ajuste da solução de tório para o seu uso na alimentação das colunas verticais pulsadas. O nitrato de tório era extraído com a mistura formada por fosfato de tri-n-butila (TBP) com varsol, sendo a concentração de 40 a $45 \%$ de varsol em volume. O nitrato de tório contido na fase orgânica era lavado com uma solução diluída de nitrato de tório. Após a lavagem revertia-se o nitrato de tório da fase orgânica utilizando-se de uma solução de ácido nítrico $0,3 \mathrm{~mol} \cdot \mathrm{L}^{-1}$.

No processo de extração por solvente na prática restava uma solução residual, o "refugado", contendo praticamente as terras raras, impurezas metálicas e tório não extraído. Esta solução era precipitada com solução de hidróxido de sódio a uma temperatura de $90^{\circ} \mathrm{C}$, com o ajuste de $\mathrm{pH}$ entre 10 e 12. Este resíduo precipitado foi denominado RETOTER (esíduo de Tório e Terras Raras). Por filtração a vácuo separava-se o precipitado. No filtrado fazia-se o teste para se detectar a presença de tório e terras raras, pela reação com solução de ácido oxálico. No caso de ausência de tório e terras raras liberava-se o filtrado para a rede de esgoto ${ }^{[20,26]}$. Periodicamente coletava-se uma amostra e encaminhava-se para o Laboratório de Radiometria Ambiental (LRA) para a determinação dos radionuclídeos. Fazia-se o controle dos radionuclídeos baseado na norma CNEN-NE-06 antes de liberar o efluente para a rede de esgoto. Depois o RETOTER era transferido para as embalagens (tambores de aço ou bombonas de polietileno) de capacidade 200 litros ou de 100 litros, respectivamente, para ser armazenado no depósito de Salvaguardas do IPEN. 
Produziu-se e estocou-se o RETOTER no período de Janeiro de 1985 a Dezembro de 1999. A partir do ano 2000 até o encerramento da produção de nitrato de tório em Maio de 2002, não se gerou mais o RETOTER, pois houve uma mudança no processo e este material parou de ser produzido. As embalagens utilizadas para estocarem o RETOTER foram os tambores de aço carbono e as bombonas de polietileno, que com o tempo sofreram um processo de corrosão e rachaduras, respectivamente e, portanto ficaram deteriorados. Devido ao problema de corrosão dos tambores e das rachaduras nas bombonas todos estes recipientes foram substituídos por novas embalagens de polietileno por medida de segurança.

Na FIG.1.3.4.1 tem-se o diagrama de bloco do processo de purificação de nitrato de tório a partir do ano 2000 . 


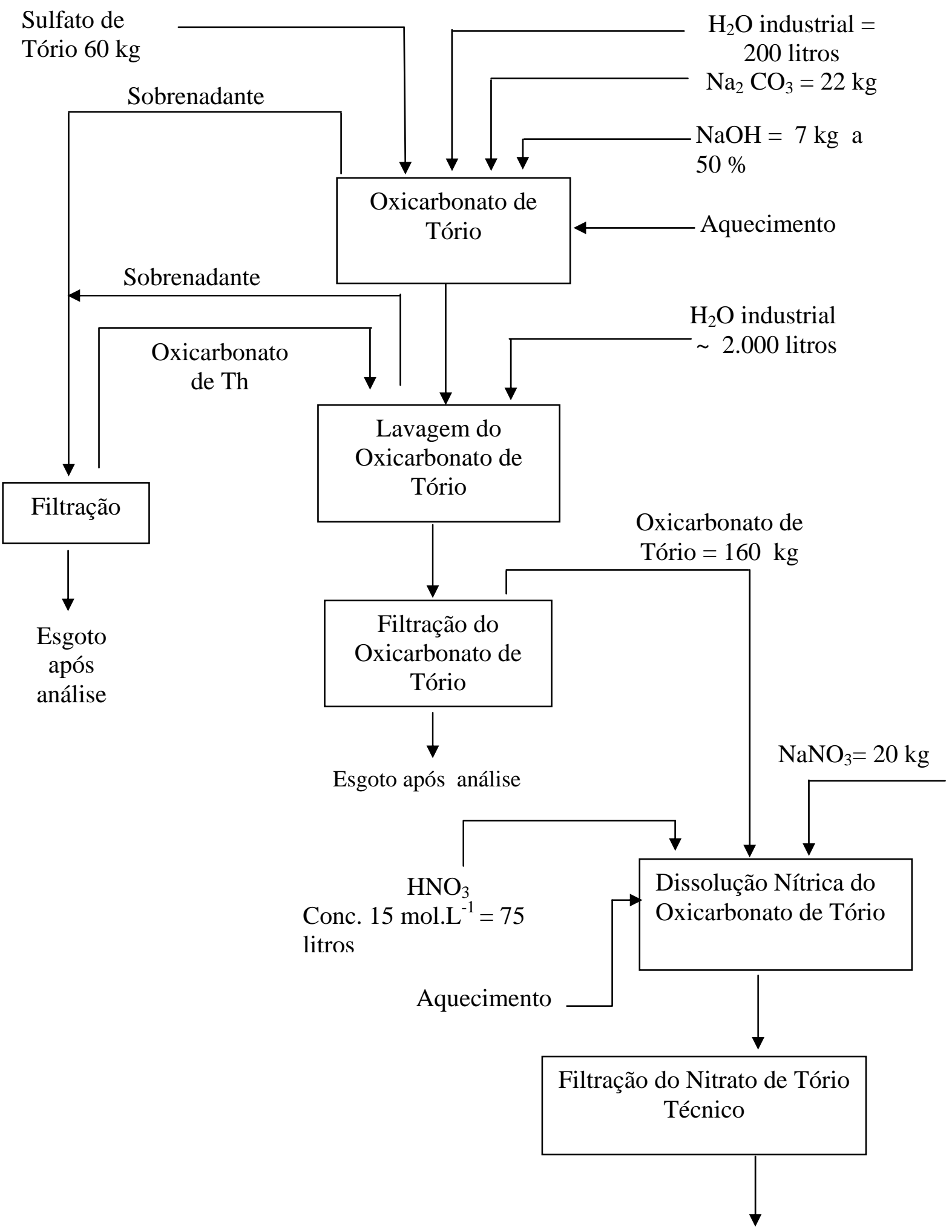

Nitrato de Tório Técnico

FIGURA 1.3.4.1 - Diagrama de bloco do processo de purificação do nitrato de tório 
A unidade de produção de nitrato de tório no IPEN durante o período de operação processou cerca de 160 toneladas de sulfato de tório bruto para a produção de nitrato de tório de elevada pureza. A mencionada unidade localizavase no antigo Departamento de Engenharia Química da Diretoria de Materiais do IPEN/CNEN-SP, hoje Centro de Química e Meio Ambiente (CQMA). Sua maior contribuição foi suprir as indústrias nacionais de camisas incandescentes para lampião, para atender as necessidades da sociedade brasileira e de alguns países. Outras contribuições se deram também nas áreas de pesquisas do ciclo do combustível e de outros setores interessados no uso do tório. Na FIG 1.3.4.2 tem-se uma vista da unidade de produção de nitrato de tório.

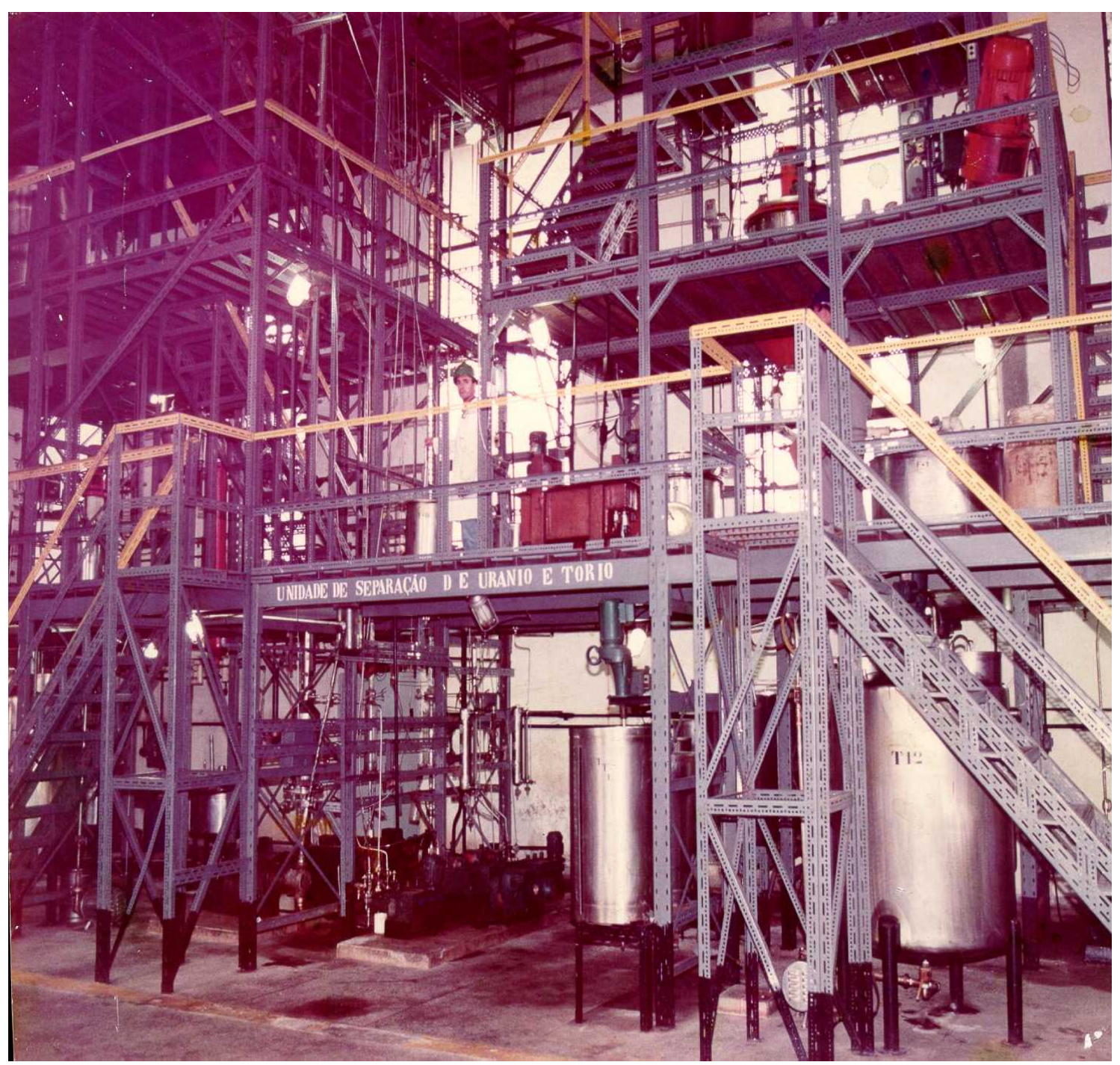

FIGURA 1.3.4.2 - Unidade de Purificação de Tório 
A produção de nitrato de tório variou de duas toneladas/mês nos primeiros anos para 0,4 toneladas/mês nos últimos anos. Um dos fatores para esta diminuição de produção de nitrato de tório deve-se a sua substituição por ítrio na fabricação das camisas incandescentes para lampião. Passou-se a utilizar o ítrio, uma das terras raras, em lugar do tório, pois o ítrio não é radioativo.

Durante o período de produção de nitrato de tório a instalação do IPEN foi a única no país disponibilizada para a mencionada tarefa.

\subsection{5 - Principais clientes}

O período de produção do nitrato de tório iniciou-se em janeiro de 1985 e encerrou-se em maio de 2002. Durante este período houve apenas uma interrupção na produção de nitrato de tório que permaneceu por 13 meses entre os anos de 1995 e 1996. Isto ocorreu devido a um problema de infiltração existente no piso da instalação, e também porque tínhamos um estoque estratégico para atender aos pedidos dos clientes sem necessidade de produzir. Os clientes consumidores eram: M. Agostini S/A Ind. e Com., Metal Yanes e Kynas e Fonseca Ltda com uma demanda média de $600 \mathrm{~kg} / \mathrm{mês}, 400 \mathrm{~kg} / \mathrm{mês}$ e $200 \mathrm{~kg} / \mathrm{mês}$, respectivamente. Os três clientes iniciaram as suas aquisições na mesma época, porém o encerramento ocorreu em tempos diferentes, conforme descreveremos abaixo: Kynas e Fonseca Ltda encerrou as suas retiradas em 1991, a Metal Yanes em 1994, e a M.Agostini encerrou em maio de 2002. As três firmas utilizavam o tório para a fabricação de camisas incandescentes para lampião. Um dos motivos que causou a parada do consumo de nitrato de tório pelos clientes citados acima foi a substituição da matéria prima (nitrato de tório) pelo elemento ítrio, por motivo de o ítrio não ser um material radioativo.

\subsection{6 - Descrição da instalação de fabricação de camisas incandescentes para lampião M. Agostini ${ }^{[27]}$}

Várias indústrias produziam camisas incandescentes para o uso em lampião a gás no Brasil, dentre elas citaremos a indústria M.Agostini Comércio e Indústria S.A. localizada na cidade do Rio de Janeiro. Esta indústria realizava o 
processo de fabricação de camisas incandescentes para lampião de maneira quase que semi-manual. $O$ processo de produção é mostrado no fluxograma a seguir na (FIG.1.3.6).

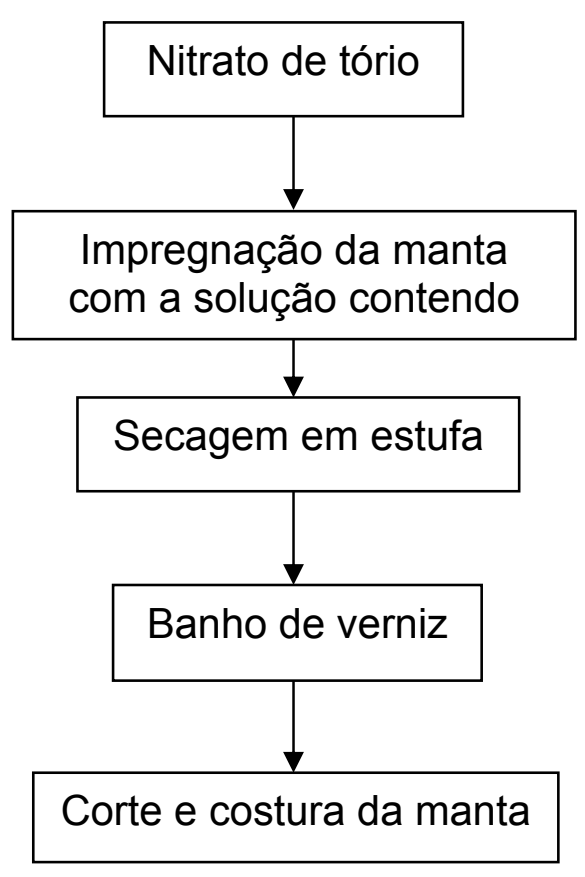

FIGURA - 1.3.6 - Esquema das principais etapas do processo de fabricação de camisas incandescentes para lampião ${ }^{[27]}$.

O processo de fabricação inicia-se com um banho da malha em uma solução diluída de ácido clorídrico seguida com amônia. Em seguida, as malhas eram centrifugadas para a retirada do excesso de solução e secas em estufas. As malhas eram então enroladas por processo semi-manual. $O$ banho de impregnação era feito usando solução contendo nitrato de tório, de cério, de alumínio e de cobalto. Para cada litro de solução eram usados $637 \mathrm{~g}$ de nitrato de tório tetra hidratado, sendo necessários $6,7 \mathrm{~mL}$ desta solução para impregnar $1 \mathrm{~m}$ de malha. Após a impregnação, as malhas eram centrifugadas e desembaraçadas por processo semi-manual, seguindo então para secagem em estufa. Após a secagem as malhas eram tratadas com solução de $\mathrm{NH}_{4} \mathrm{OH}$, sendo novamente centrifugadas, desembaraçadas por processo semi-manual e colocadas em estufas para secagem. Depois as malhas recebiam banho de verniz, com o 
objetivo de fixar o material impregnado. Após a secagem do verniz, as mantas seguiam para o setor de corte e costura. A etapa de corte e costura era considerada pela empresa como área livre de contaminação. A manta era cortada em diversos pedaços de $150 \mathrm{~mm}$ cada, que em seguida eram costurados em uma das pontas. A ponta sem costura recebia uma camada de tinta para reforço e acabamento. Após secagem em estufa, a camisa recebia o acabamento final ${ }^{[27]}$. 


\section{CAPÍTULO 2}

\section{PARTE EXPERIMENTAL}

Os experimentos foram realizados nos laboratórios do Centro de Química e Meio Ambiente/IPEN, utilizando-se de sua infra-estrutura em equipamentos e reagentes.

\section{1 - Equipamentos}

- placa aquecedora com agitador magnético - Quimus, Mod.Q 261.2

- termômetro - Incotem; penagômetro - Micronal, Mod B371

- mufla - Fornitec, Modelo 1913 ( 20 - $1.200^{\circ} \mathrm{C}$ )

- estufa $\left(50-200^{\circ} \mathrm{C}\right)$

- balança analítica - Quimus, Mod Q500L210C

- espectrômetro de energia gama (Nal)

- espectrometria gama HPGe.

\section{2 - Reagentes}

- Nitrato de bário $1 \mathrm{~mol} . \mathrm{L}^{-1}$

- Solução de sulfato de amônio 20\%

- Peróxido de hidrogênio $30 \%$ v/v

- Solução de ácido oxálico 15\%

- Solução de carbonato de amônio $1 \mathrm{~mol} . \mathrm{L}^{-1}$

- Solução de ácido nítrico 2, 4, 6, e 8 mol.L-1

- Hidróxido de amônio 1:1

- Sal dissódico do ácido etilenodiaminotetraacético (EDTA)

- Isoparafina. 


\section{CAPÍTULO 3}

\section{CARACTERIZAÇÕES}

No depósito de SALVAGUARDAS do IPEN/SP fez-se uma amostragem do RETOTER. Realizou-se a coleta de várias amostras de diversas bombonas de polietileno, onde se encontra estocado o rejeito de tório e de terras raras. O local do depósito é uma área controlada e restrita sob o ponto de vista de radioproteção.

Devido às condições esta área fica restrita sob um controle rigoroso ao acesso do local, decorrente do risco associado à estimativa de dose efetiva ocupacional e, portanto, restringindo bastante o tempo de permanência do trabalhador. A amostragem para este trabalho foi feita com muita cautela e planejamento. Então se trabalhou dentro do controle estabelecido pelas normas de radioproteção que exigiam o menor tempo possível de exposição no local. O plano de como realizar a retirada das amostras foi elaborado pelo próprio pessoal que gerou o material, portanto, por pessoas experientes com o manuseio do RETOTER.

O RETOTER estudado foi produzido a partir da mesma matéria-prima, ou seja, do sulfato de tório produzido pela Orquima, cujas características são semelhantes e foi processado utilizando-se um processo rotineiro com os parâmetros já estabelecidos. Portanto, esta amostragem nos leva a uma probabilidade grande de que a sua caracterização seja muito parecida com o montante de RETOTER que temos armazenado no depósito de Salvaguardas.

\section{1 - Caracterização química do RETOTER}

Utilizaram-se 8 bombonas para a coleta de amostra. Cada bombona continha em média $150 \mathrm{~kg}$ de RETOTER úmido. Foram retiradas quantidades 
aproximadamente iguais de cada bombona, e coletaram-se no total $33 \mathrm{~kg}$ de amostra. Estas amostras foram colocadas em um recipiente, no qual se fez uma homogeneização mecânica constante e eficiente. Monitorou-se o material coletado e a medida da taxa de exposição encostado à amostra foi de $800 \mu$ sievert/hora. O processo de homogeneização foi realizado por um período de 26 horas. O material apresentou-se com o aspecto pastoso, bastante uniforme e coloração marrom. Após a preparação da amostra fez-se a determinação de umidade no laboratório analítico de processos químicos e encaminhou-se uma amostra para o laboratório de espectrometria de fluorescência de Raios-X do CQMA para a determinação dos teores dos elementos constituintes.

Determinações analíticas:

Teor de umidade do $\underline{\text { RETOTER }}$

Uma porção da amostra de RETOTER foi seca em estufa à temperatura de $120^{\circ} \mathrm{C}$ até peso constante e encontrou-se o teor de umidade igual a $68,18 \%$ da massa inicial.

A composição química do RETOTER varia levemente de acordo com o lote.

Determinação química. Os teores dos elementos foram determinados por espectrometria de fluorescência de Raios-X por dispersão de comprimento de onda (WDXRF), em amostra seca.

$\mathrm{Na}$ TAB.3.1.1 encontram-se os teores dos elementos determinados por espectrometria de fluorescência de Raios-X (WDXRF) ${ }^{[28]}$.

TABELA 3.1.1 -Resultados da análise por espectrometria de fluorescência de Raios-X

\begin{tabular}{cccc}
\hline Constituinte & Teor \% & Constituinte & Teor \% \\
\hline $\mathrm{ThO}_{2}$ & 67,90 & $\mathrm{U}_{3} \mathrm{O}_{8}$ & 0,30 \\
$\mathrm{P}_{2} \mathrm{O}_{5}$ & 3,40 & $\mathrm{Nd}_{2} \mathrm{O}_{3}$ & 0,40 \\
$\mathrm{SiO}_{2}$ & 0,67 & $\mathrm{CaO}$ & 1,20 \\
$\mathrm{Na}_{2} \mathrm{O}$ & 18,40 & $\mathrm{PbO}$ & 1,20 \\
$\mathrm{Fe}_{2} \mathrm{O}_{3}$ & 1,50 & $\mathrm{ZrO}$ & 0,67 \\
$\mathrm{SO}_{3}$ & 1,00 & $\mathrm{Cl}$ & 0,43 \\
$\mathrm{CeO}_{2}$ & 0,83 & $\mathrm{MgO}$ & 0,67 \\
$\mathrm{TiO}_{2}$ & 1,20 & $\mathrm{NiO}$ & 0,09 \\
$\mathrm{Al}_{2} \mathrm{O}_{3}$ & 0,13 & $\mathrm{ZnO}$ & 0,03 \\
\hline
\end{tabular}




\section{$\underline{\text { Tório }} \underline{\text { e Terras }} \underline{\text { Raras }}$}

Além do método de análise por espectrometria de fluorescência de Raios-X as determinações de tório e de terras raras, também podem ser realizadas por gravimetria e por titulação complexométrica com EDTA. Para essas determinações utilizam-se os métodos de determinação da concentração de tório por titulação complexante ${ }^{[29]}$, e para a determinação da concentração de óxidos totais de terras raras por gravimentria ${ }^{[30]}$.

O RETOTER contém ainda elementos em menores teores como é o caso das impurezas metálicas. Estas impurezas metálicas foram analisadas por espectrografia de emissão óptica ${ }^{[31]}$, e os resultados encontram-se na (TAB. 3.1.2).

TABELA 3.1.2 - Análise por espectrografia de emissão óptica de elementos menores no RETOTER.

\begin{tabular}{cc}
\hline Elemento & Teor \% \\
\hline $\mathrm{Cd}$ & $<0,2$ \\
$\mathrm{Zn}$ & 0,15 \\
$\mathrm{P}$ & 0,15 \\
$\mathrm{Ca}$ & 0,25 \\
$\mathrm{Zr}$ & 3,0 \\
$\mathrm{Ti}$ & 0,3 \\
\hline
\end{tabular}

\section{2 - Caracterização radioativa do RETOTER}

A caracterização radioativa das frações (Tório, TR, Resíduo, Ba(Ra)SO 4 ) das amostras obtidas nas etapas do processo de fracionamento do RETOTER foi feita utilizando-se a espectrometria gama. Em linhas gerais, a espectrometria gama pode ser entendida como um processo baseado na interação da radiação gama emitida pela amostra com o detector, possibilitando a discriminação qualitativa e quantitativa dos radioisótopos presentes em matrizes complexas. Uma grande vantagem da espectrometria gama é a facilidade de medir a amostra de forma direta e não-destrutiva. A sua rapidez está inicialmente relacionada à 
concentração, características dos radionuclídeos de interesse e características da matriz. Um sistema genérico de detecção e aquisição de dados, por espectrometria gama de alta resolução, está simplificado na (FIG. 3.1) ${ }^{[32]}$

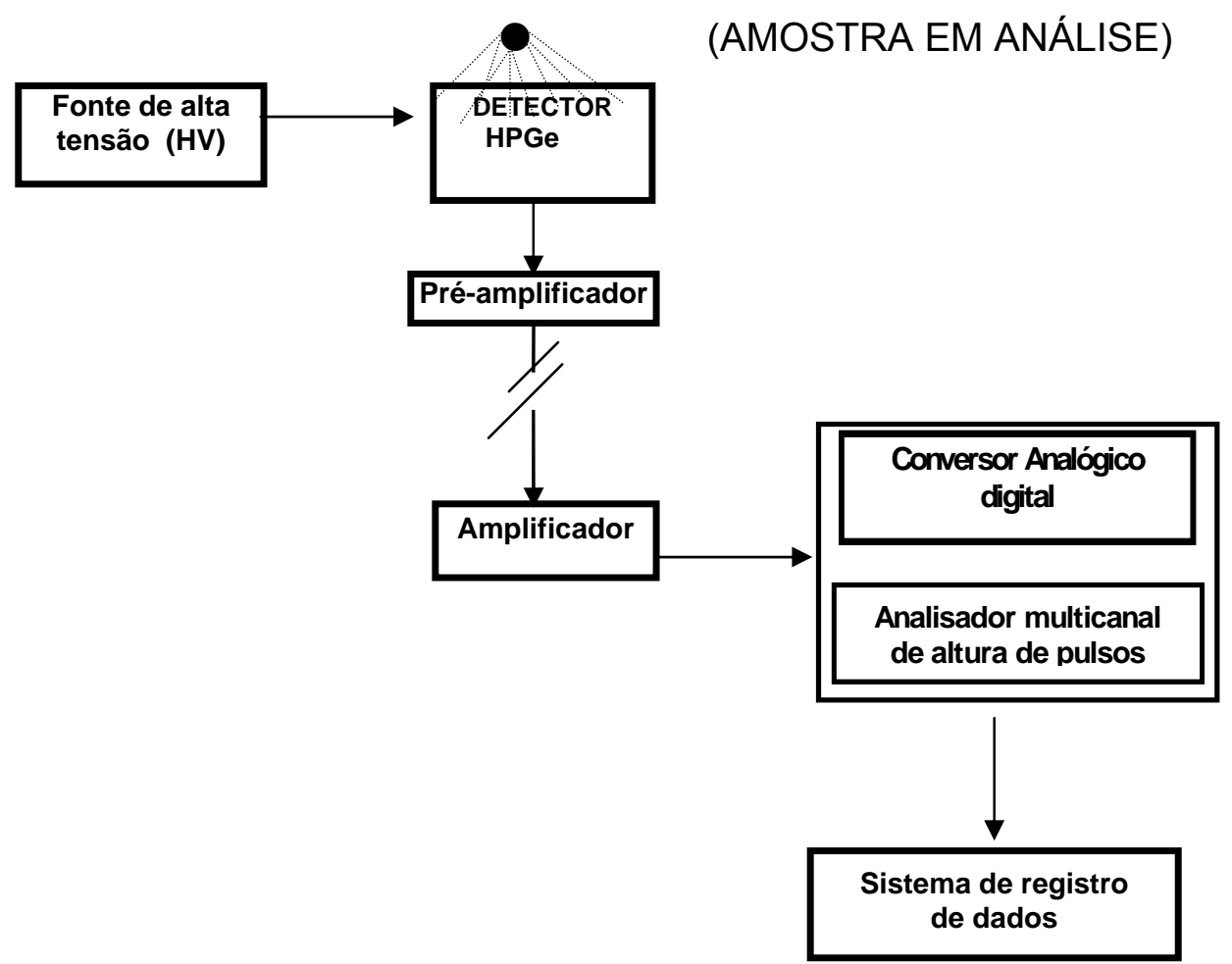

FIGURA 3.1- Fluxograma genérico do sistema de espectrometria gama.

$\mathrm{Na}$ espectrometria gama das frações geradas no processamento analítico do RETOTER empregou-se um espectrômetro gama de germânio hiperpuro, $\mathrm{HPGe}$, ligado à eletrônica associada, com $15 \%$ de eficiência relativa e resolução de $2,3 \mathrm{keV}$ para o pico de $1332 \mathrm{keV}$ do ${ }^{60} \mathrm{Co}$, com 4096 canais. O programa Maestro foi utilizado para efetuar a aquisição e gravação de dados obtidos na medida por espectrometria gama. Os espectros foram analisados empregando-se o programa Interwiner, sendo calculadas as áreas e incerteza sob os fotopicos de interesse, que são apresentados na (TAB.3.1.3) ${ }^{[32]}$. 
TABELA 3.1.3 - Energias gama e intensidades dos radionuclídeos analisados.

\begin{tabular}{ccc}
\hline Nuclídeo & Energia gama (keV) & Intensidade (\%) \\
\hline${ }^{214} \mathrm{~Pb}$ & 295,21 & 18,7 \\
${ }^{214} \mathrm{Bi}$ & 351,93 & 35,8 \\
${ }^{228} \mathrm{Ac}$ & 609,32 & 45 \\
& 911,07 & 27,8 \\
${ }^{40} \mathrm{~K}$ & 968,90 & 16,7 \\
${ }^{230} \mathrm{Th}$ & 1460,83 & 10,7 \\
${ }^{210} \mathrm{~Pb}$ & 76 & - \\
${ }^{234 \mathrm{~m}} \mathrm{~Pa}$ & 46,54 & 4,1 \\
\hline
\end{tabular}

Os radionuclídeos naturais ocorrem inicialmente como integrantes na composição de minerais e rochas e são distribuídos nos compartimentos ambientais. A atividade humana pode alterar a concentração destes radionuclídeos nos diversos compartimentos do ecossistema. As séries naturais do urânio-238 e do tório-232 são apresentadas nas (FIG. 3.2 e 3.3) ${ }^{[32]}$. 


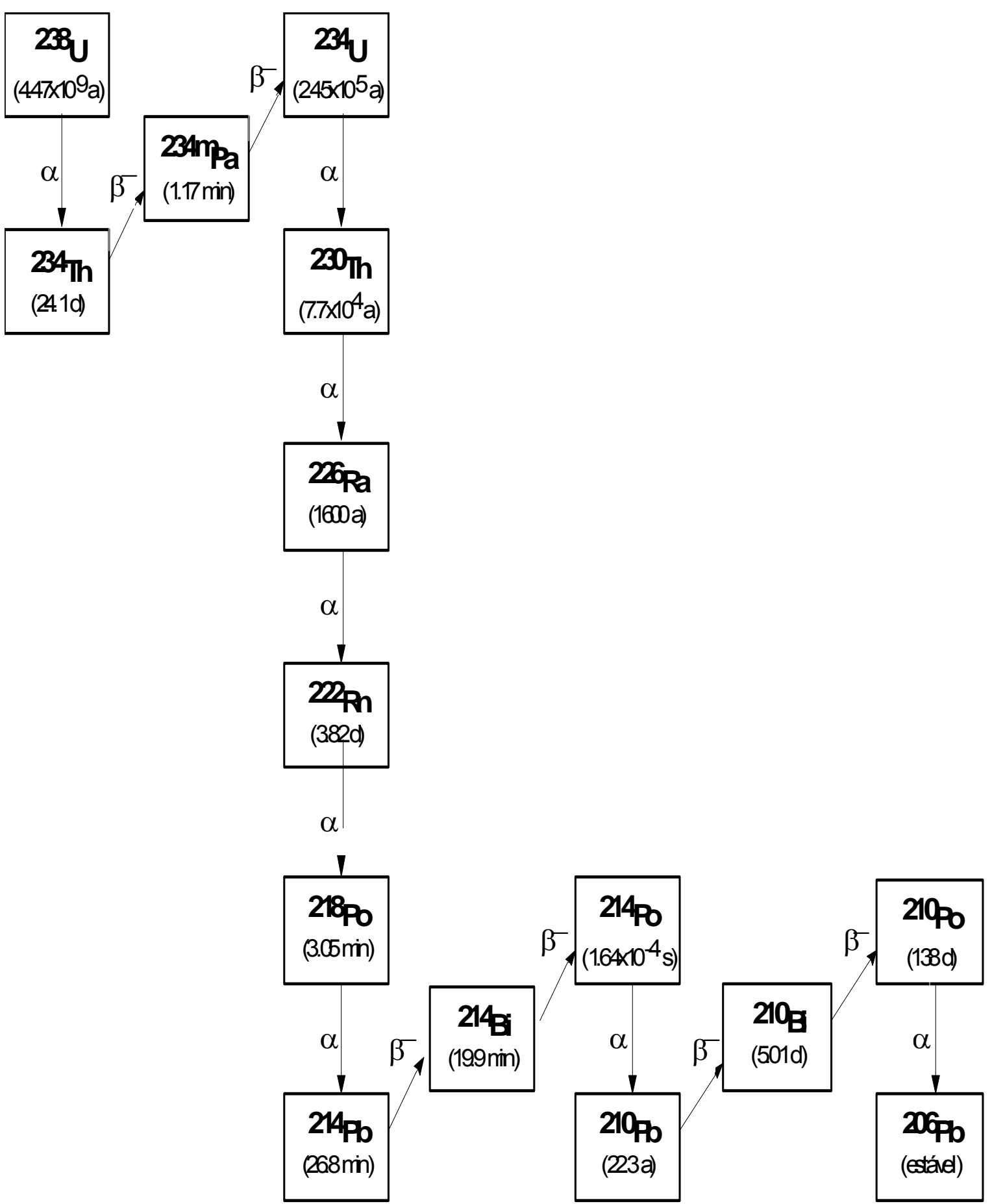

FIGURA 3.2 - Série de decaimento natural do ${ }^{238} \mathrm{U}$ (IAEA, 2000). 


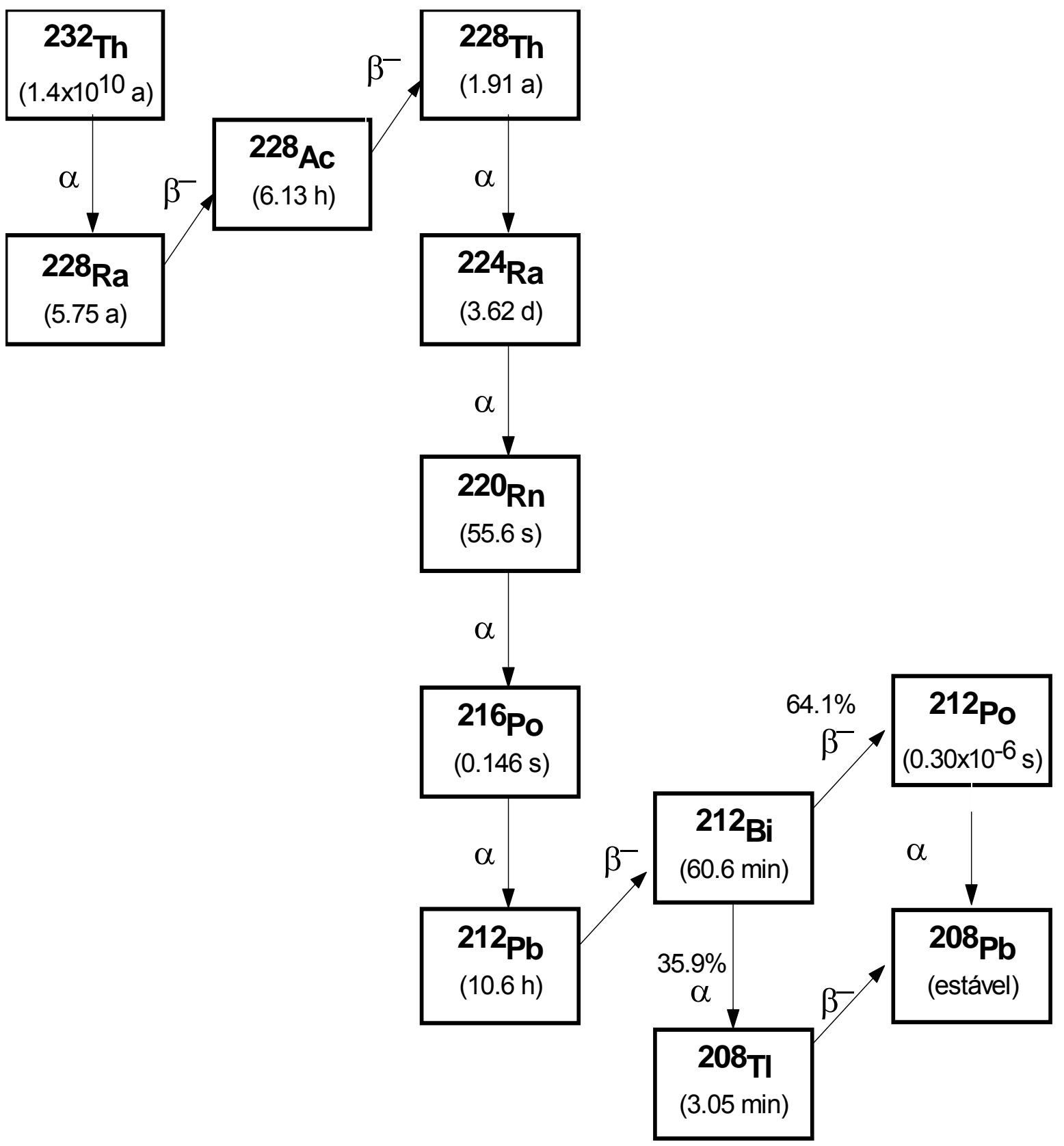

FIGURA 3.3 - Série de decaimento natural do ${ }^{232}$ Th (IAEA, 2000). 


\section{CAPÍTULO 4}

\section{METODOLOGIA}

Para o desenvolvimento da metodologia do tratamento do RETOTER, no qual se separam os elementos de valores, tório e terras raras, estudaram-se as seguintes etapas de separação: dissolução do RETOTER com ácido nítrico, precipitação do sulfato de bário para a coprecipitação do rádio usando-se nitrato de bário e sulfato de amônio. Finalmente as precipitações dos peróxidos de tório e terras raras separados, usando-se peróxido de hidrogênio.

Na FIG. 4.1 ilustra-se as etapas do processo para a separação seletiva dos compostos de interesse. 


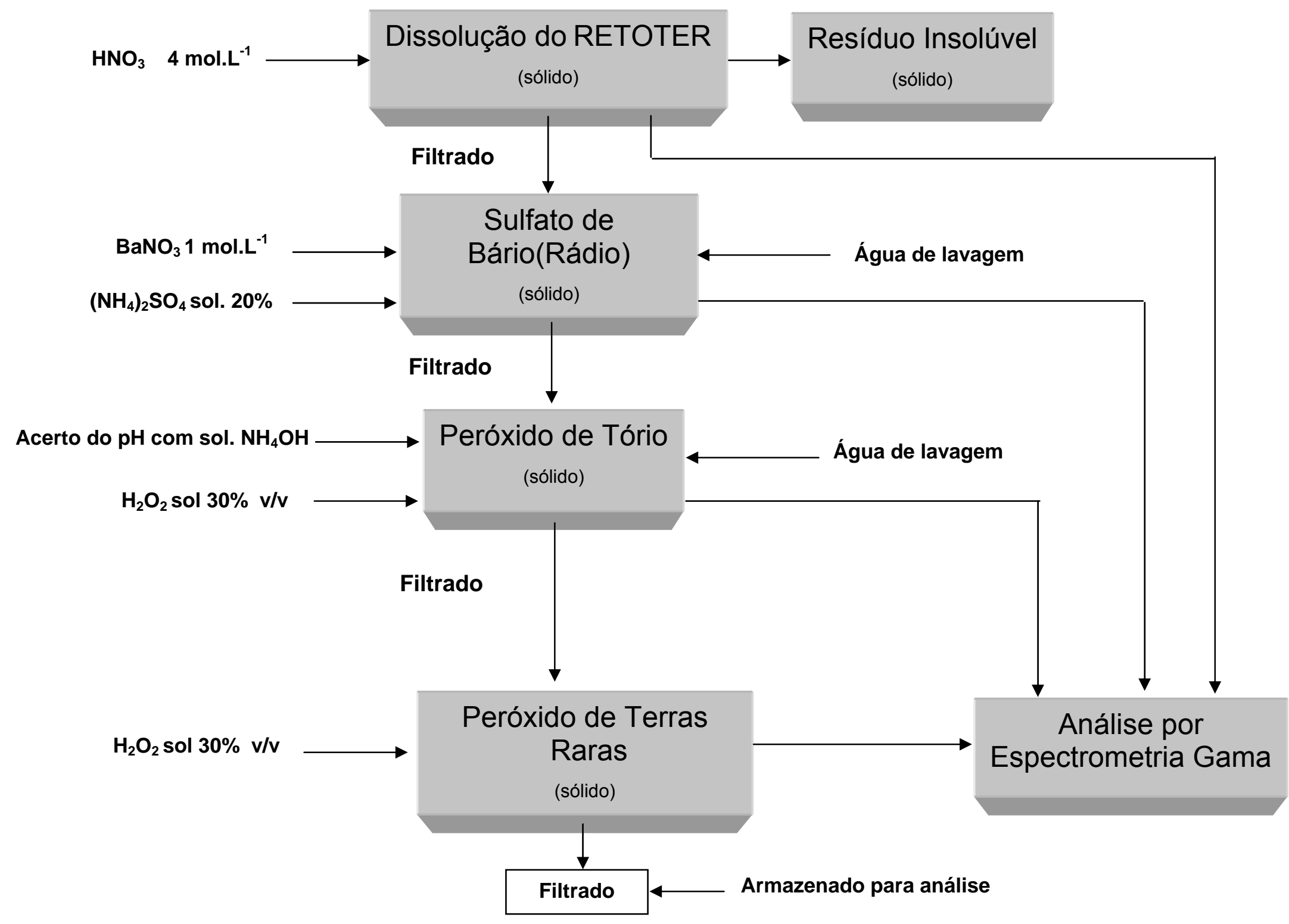

Figura 4.1 - Diagrama de bloco do processo de separação dos valores do RETOTER 


\section{1 - Separação preliminar da fase orgânica no RETOTER}

Tendo em vista a presença de fase orgânica em pequena quantidade proveniente do agente extrator do tório (fosfato de tri-n-butila), usado na sua purificação, realizaram-se ensaios para separação da fase orgânica do RETOTER.

Baseados em informações, programaram-se alguns ensaios com o objetivo de separar a fase orgânica contaminante do RETOTER ${ }^{[33]}$.

Experimento A: RETOTER tratado com isoparafina

Numa alíquota de $10 \mathrm{~g}$ de RETOTER adicionaram-se $10 \mathrm{~mL}$ de isoparafina, agitou-se por alguns minutos. Em seguida filtrou-se esta mistura. Observou-se que a filtração foi lenta, sendo realizada em 24 horas.

Experimento B: Uso de papel de filtro impregnado com isoparafina

Pesaram-se $10 \mathrm{~g}$ de RETOTER e adicionaram-se $10 \mathrm{~mL}$ de água, agitou-se por alguns minutos formando uma suspensão. Impregnou-se previamente o papel de filtro com isoparafina. Em seguida filtrou-se.

A filtração foi rápida, com o filtrado límpido e transparente, e a coloração da fase aquosa era esverdeada. No filtrado aparecem as duas fases separadas e límpidas, a aquosa que tinha sido adicionada e a orgânica que estava na mistura com o RETOTER. Portanto, conclui-se que o resultado mais satisfatório foi o do experimento $B$.

Com a separação da fase orgânica do material prosseguiu-se com os estudos para a separação seletiva do rádio, do tório e das terras raras do RETOTER, descontaminado do fostafo de tri-n-butila(TBP). 


\section{2 - Dissolução Nítrica do Retoter}

O RETOTER é um resíduo que apresenta baixa solubilidade para sua dissolução com ácidos. A escolha do ácido foi feita entre $\mathrm{HCl}, \mathrm{HNO}_{3}$ e $\mathrm{H}_{2} \mathrm{SO}_{4}$. Para esta dissertação escolheu-se o ácido nítrico. $O$ ácido sulfúrico foi considerado inconveniente porque conduz à precipitação do sulfato de tório. Evitou-se também o ácido clorídrico, uma vez que a tecnologia a ser desenvolvida pode ser colocada em pratica na indústria. Geralmente as indústrias desconsideram o ácido clorídrico para esta finalidade por ser corrosivo.

Com o objetivo de se estudar a melhor condição de dissolução do RETOTER relacionou-se a sua massa com o volume de ácido nítrico necessário à sua dissolução ${ }^{[25]}$. Então programaram-se os seguintes ensaios:

1 - experimentos com várias concentrações de ácido nítrico;

2 - experimentos variando-se as proporções de massa de retoter por volume de ácido nítrico.

Nos experimentos as concentrações de ácido nítrico foram: 2, 4, 6 e 8 mol. $L^{-1}$.

Nos experimentos com várias relações de ácido nítrico para uma massa fixa de RETOTER trabalhou-se da seguinte forma: Relação massa de RETOTER por volume de ácido nítrico: 1:1, 1:3 e 1:5.

Considerou-se que em experimentos exploratórios de dissolução do RETOTER com ácido nítrico, a técnica mais conveniente era adicionar o RETOTER sobre o ácido. Assim, neste trabalho, adotou-se o seguinte procedimento:

Adicionou-se em primeiro lugar o ácido nítrico no reator e depois lentamente adicionou-se o RETOTER sobre o ácido, sempre sob agitação. Logo após as alimentações notou-se que a reação de dissolução iniciou-se à temperatura ambiente, porém lentamente e com liberação de gases. A reação mostrou-se exotérmica, no início. Após alguns minutos de agitação, iniciou-se o 
aquecimento até $80^{\circ} \mathrm{C}$, o qual foi mantido por 4 horas, sempre sob agitação magnética.

Reação de dissolução:

$\mathrm{Th}(\mathrm{OH})_{4(\mathrm{~s})}+\mathrm{TR}(\mathrm{OH})_{3(\mathrm{~s})}+7 \mathrm{HNO}_{3}=\mathrm{Th}\left(\mathrm{NO}_{3}\right)_{4(\mathrm{aq})}+\mathrm{TR}\left(\mathrm{NO}_{3}\right)_{3(\mathrm{aq})}+7 \mathrm{H}_{2} \mathrm{O}+$ resíduo $^{[7]}$

Várias dissoluções foram feitas seguindo-se o procedimento:

- relação RETOTER /ácido nítrico 1:1(m/v), variando-se a concentração do ácido em 2, 4, 6 e 8 mol.L $\mathrm{L}^{-1}$.

- relação RETOTER lácido nítrico 1:3(m/v), variando-se a concentração do ácido em 2, 4, 6 e 8 mol. $\mathrm{L}^{-1}$.

- um outro número de experimentos foi feito com a relação (RETOTER/ácido nítrico $)=1: 5(\mathrm{~m} / \mathrm{v})$, variando-se a concentração do ácido em 2, 4, 6 e $8 \mathrm{~mol} \cdot \mathrm{L}^{-1} . \mathrm{Na}$ TAB. 4.2.1 apresentam-se as condições.

TABELA 4.2.1 - Estudo da variação das relações massa RETOTER/volume e concentração do ácido nítrico.

Relação 1:1

\begin{tabular}{ccccc}
\hline Experimento & $\begin{array}{c}\text { Concentração } \\
\text { de } \mathrm{HNO}_{3} \\
\left(\mathrm{~mol}_{\mathrm{l}} \mathrm{L}^{-1}\right)\end{array}$ & $\begin{array}{c}\text { Vol. de } \\
\mathrm{HNO}_{3} \\
(\mathrm{~mL})\end{array}$ & $\begin{array}{c}\text { Massa de } \\
\text { RETOTER }\end{array}$ & $\begin{array}{c}\text { Coloração da } \\
\text { suspensão }\end{array}$ \\
1 & 2 & 10 & 10 & marrom claro \\
2 & 4 & 10 & 10 & Esverdeada \\
3 & 6 & 10 & 10 & Marrom \\
4 & 8 & 10 & 10 & Marrom
\end{tabular}

Relação 1:3

$\begin{array}{lllll}5 & 2 & 30 & 10 & \text { Marrom } \\ 6 & 4 & 30 & 10 & \text { Marrom } \\ 7 & 6 & 30 & 10 & \text { Esverdeada } \\ 8 & 8 & 30 & 10 & \text { Esverdeada }\end{array}$

Relação 1:5

\begin{tabular}{ccccc}
9 & 2 & 50 & 10 & Esverdeada \\
10 & 4 & 50 & 10 & Esverdeada \\
11 & 6 & 50 & 10 & Esverdeada \\
12 & 8 & 50 & 10 & Esverdeada \\
\hline
\end{tabular}


Relação 1:1

O experimento 1 apresentou muito resíduo (partículas finas) e uma coloração marrom claro. $O$ experimento 2 apresentou menos resíduo e uma coloração esverdeada e durante o aquecimento apresentou-se mais límpida do que o experimento 1. $O$ experimento 3 durante o aquecimento apresentou menos transparência que o experimento 4. Ambos os experimentos apresentaram a coloração marrom.

\section{Relação 1:3}

O experimento 6 durante o aquecimento apresentou-se mais transparente que o experimento 5 ambos apresentaram uma coloração marrom. $O$ experimento 8 durante o aquecimento apresentou-se mais límpido que o experimento 7 e ambos os experimentos apresentaram uma coloração esverdeada.

\section{Relação 1:5}

Durante as duas primeiras horas de realização dos experimentos 9 e 10 , estes foram os que se apresentaram mais límpidos. Mas depois de algum tempo os aspectos dos dois ficaram iguais. Porém, depois de algumas horas de repouso, notou-se que o material do experimento 10 apresentava melhor sedimentação. As duas misturas apresentavam uma coloração esverdeada. Com relação aos experimentos 11 e 12 nota-se o seguinte: o experimento 12 apresentou material mais límpido que o do experimento 11. Ambos apresentaram coloração esverdeada.

Observa-se que:

1 - A solução mais límpida demonstra que ocorreu melhor dissolução do RETOTER.

2 - Todos os experimentos apresentaram resíduos que aparentam ser sílica e matéria orgânica na superfície após o tratamento com ácido. 
Efetuaram-se mais três experimentos que foram identificados como Lotes 02, 03, e 04, seguindo os mesmos procedimentos adotados e descritos anteriormente neste capítulo. Os experimentos foram realizados para se obter mais dados de análises. Na TAB. 4.2.2 estão relacionadas às quantidades de reagentes que foram utilizados em cada um e as condições de trabalho que foram as mesmas dos experimentos anteriores.

TABELA 4.2.2 - Relação (massa de RETOTER/volume de ácido nítrico)1:5 utilizada nos lotes 02,03 e 04 .

\begin{tabular}{cccc}
\hline Experimento & $\begin{array}{c}\text { Concentração de } \mathrm{HNO}_{3} \\
\left(\text { mol. } L^{-1}\right)\end{array}$ & $\begin{array}{c}\text { Vol. de } \mathrm{HNO}_{3} \\
(\mathrm{~mL})\end{array}$ & $\begin{array}{c}\text { Massa de } \\
\text { RETOTER } \\
(\mathrm{g})\end{array}$ \\
\hline Lote 02 & & 50 & 10 \\
Lote 03 & 4 & 50 & 10 \\
Lote 04 & 4 & 50 & 10 \\
\hline
\end{tabular}

\section{3 - Filtrações e lavagens dos resíduos}

As filtrações foram feitas utilizando-se o papel de filtro faixa azul (filtração lenta). Inicialmente fizeram-se as filtrações das suspensões e depois lavaram-se os resíduos com água desionizada. Os resíduos dos experimentos da relação (RETOTER/ácido nítrico) 1:1 foram lavados com 3 ou $4 \mathrm{~mL}$ de água desionizada cada e juntaram-se as águas de lavagens aos filtrados. Os resíduos dos experimentos das relações (RETOTER/ácido nítrico) 1:3 e 1:5 foram lavados com $10 \mathrm{~mL}$ de água desionizada cada um deles e as águas de lavagens foram recolhidas separadamente dos filtrados. No caso da relação (RETOTER/ácido nítrico) 1:1, juntaram-se os volumes das águas de lavagem de cada experimento porque o volume era pequeno e diluiria pouca a solução obtida. Mas no caso das relações 1:3 e 1:5, como os volumes das águas de lavagem eram maiores e ocorreriam diluições maiores das soluções iniciais, então resolveu-se recolhe-las separadamente. Na TAB. 4.2.3 encontram-se os resultados. 
TABELA 4.2.3 - Estudo das filtrações dos resíduos após o tratamento do RETOTER com ácido nítrico em várias concentrações.

Relação 1:1

\begin{tabular}{|c|c|c|c|c|c|}
\hline Experimento & $\begin{array}{c}\text { Conc. } \\
\mathrm{HNO}_{3} \\
\left(\mathrm{~mol}^{-1} \mathrm{~L}^{-1}\right)\end{array}$ & $\begin{array}{l}\text { Condições da } \\
\text { filtração }\end{array}$ & $\begin{array}{l}\text { Vol. do } \\
\text { filtrado e } \\
\text { água de } \\
\text { lavagem } \\
(\mathrm{mL})\end{array}$ & $\begin{array}{l}\text { Coloração } \\
\text { da } \\
\text { suspensão }\end{array}$ & Observações \\
\hline 1 & 2 & $\begin{array}{c}\text { muito lenta e } \\
\text { passou } \\
\text { material }(1,1 / 2 \\
\text { dia })\end{array}$ & 23 & amarela & $\begin{array}{c}\text { filtrou-se três } \\
\text { vezes }\end{array}$ \\
\hline 2 & 4 & $\begin{array}{c}\text { muito lenta e } \\
\text { não passou } \\
\text { material( } 1,1 / 2 \\
\text { dia) }\end{array}$ & 26 & esverdeada & filtração normal \\
\hline 3 & 6 & $\begin{array}{c}\text { média e não } \\
\text { passou } \\
\text { material }\end{array}$ & 28 & esverdeada & filtração normal \\
\hline 4 & 8 & $\begin{array}{c}\text { muito lenta e } \\
\text { passou } \\
\text { material }\end{array}$ & 28 & esverdeada & $\begin{array}{c}\text { filtrou-se duas } \\
\text { vezes }\end{array}$ \\
\hline \multicolumn{6}{|l|}{ Relação 1:3 } \\
\hline 5 & 2 & $\begin{array}{c}\text { muito lenta e } \\
\text { passou } \\
\text { material } \\
(10 \text { horas })\end{array}$ & 25 & amarela & $\begin{array}{c}\text { filtrou-se duas } \\
\text { vezes }\end{array}$ \\
\hline 6 & 4 & $\begin{array}{c}\text { muito lenta e } \\
\text { transparente } \\
(10 \text { horas })\end{array}$ & 30 & esverdeada & filtração normal \\
\hline 7 & 6 & $\begin{array}{c}\text { média e } \\
\text { transparente } \\
\text { (8 horas e } 30 \\
\text { min) }\end{array}$ & 27 & esverdeada & filtração normal \\
\hline 8 & 8 & $\begin{array}{c}\text { rápida e } \\
\text { transparente } \\
\left(\begin{array}{c}6 \text { horas e } 30 \\
\text { min })\end{array}\right.\end{array}$ & 30 & esverdeada & filtração normal \\
\hline
\end{tabular}


Relação 1:5

\begin{tabular}{|c|c|c|c|c|c|}
\hline Experimento & $\begin{array}{c}\text { Concentração } \\
\text { de } \mathrm{HNO}_{3} \\
\left(\mathrm{~mol}^{-1} \mathrm{~L}^{-1}\right)\end{array}$ & $\begin{array}{l}\text { Condições da } \\
\text { filtração }\end{array}$ & 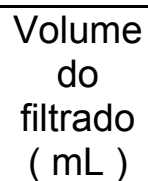 & $\begin{array}{l}\text { Coloração } \\
\text { da } \\
\text { suspensão }\end{array}$ & Observações \\
\hline 9 & 2 & $\begin{array}{c}\text { muito lenta e } \\
\text { passou } \\
\text { material } \\
(8 \text { horas ) }\end{array}$ & 51 & esverdeada & $\begin{array}{c}\text { filtrou-se duas } \\
\text { vezes }\end{array}$ \\
\hline 10 & 4 & $\begin{array}{c}\text { média e não } \\
\text { passou } \\
\text { material } \\
\text { ( } 4 \text { horas ) }\end{array}$ & 55 & esverdeada & $\begin{array}{c}\text { filtrou-se } \\
\text { normal }\end{array}$ \\
\hline 11 & 6 & $\begin{array}{l}\text { rápida e não } \\
\text { passou } \\
\text { material } \\
\text { (1 h e } 40 \mathrm{~min})\end{array}$ & 46 & esverdeada & $\begin{array}{c}\text { filtrou-se } \\
\text { normal }\end{array}$ \\
\hline 12 & 8 & $\begin{array}{c}\text { rápida e não } \\
\text { passou } \\
\text { material } \\
(1 \mathrm{~h} \text { e } 50 \mathrm{~min})\end{array}$ & 50 & esverdeada & $\begin{array}{c}\text { filtrou-se } \\
\text { normal }\end{array}$ \\
\hline
\end{tabular}

Em resumo, considerando-se os experimentos de relação 1:1 (RETOTER/ácido), os experimentos 1, 2 e 4 apresentaram filtração lenta e os experimentos 1 e 4 continham sólidos no filtrado. Já no experimento 3 ( ácido 6 mol. $\mathrm{L}^{-1}$ ) filtrou melhor, com menor tempo e com o filtrado límpido, com menor quantidade de resíduo. Acredita-se que estes resultados possam ser melhorados, razão pela qual serão feitos novos experimentos com as relações 1:3 e 1:5.

Na série com relação 1:3 (RETOTER/ácido), os experimentos 5 a 8, este foi o que filtrou mais rapidamente, mas apresentando quantidade de resíduo apreciável. O experimento 6 filtrou mais devagar, porém com menos insolúveis. Nesta série considera-se que o experimento 6 foi o melhor, dissolvendo mais RETOTER e a filtração aceitável.

$\mathrm{Na}$ série de experimentos com relação 1:5 (RETOTER/ácido), os experimentos 9 a 12, os dois últimos tiveram menores tempos de filtração (1h 40 min. e 1 h 50 min, respectivamente). O experimento 10 teve um tempo de filtração de 4 horas, apresentando menos resíduo. Pode ser considerado um modelo 
razoável para a dissolução do RETOTER. Portanto, a metodologia considerada para a dissolução nítrica como modelo adotado é a do experimento 10 .

Nas soluções de nitrato de tório impuro resultante das dissoluções com relação 1:5 (RETOTER/ácido) os experimentos $9,10,11$, e 12 foram analisados e os resultados são mostrados na TAB. (5.2) no capítulo 5 .

\subsection{1 - Resíduos}

Utilizando-se ácido nítrico e aquecimento procurou-se dissolver totalmente o RETOTER, mas não se conseguiu. Sempre sobrava um resíduo. Os resíduos das filtrações de cada experimento foram secos a $150^{\circ} \mathrm{C}$ e depois calcinados a $843^{\circ} \mathrm{C}$ durante duas horas, para se determinar as quantidades de insolúveis de cada experimento. As massas finais encontram-se na (TAB. 5.3) no capítulo 5.

\section{4 - Preparação da solução de alimentação para o estudo da separação dos valores do RETOTER}

Depois dos estudos realizados e estabelecidas as condições de dissolução do RETOTER, preparou-se uma quantidade maior de solução que possibilitaría a realização de vários experimentos, partindo-se do mesmo lote. Então prosseguiuse para preparar o lote que seria utilizado nos trabalhos de separação do rádio, do tório e das terras raras. Por motivo de dificuldade técnica para a realização do experimento de uma única vez, fez-se então três dissoluções idênticas e juntaram-se em um mesmo recipiente. Depois homogenizou-se a solução. Cada uma dessas três dissoluções foi realizada da seguinte maneira:

Utilizou-se para cada uma das dissoluções $200 \mathrm{~g}$ de RETOTER para um volume de $1000 \mathrm{~mL}$ de ácido nítrico $4 \mathrm{~mol} . \mathrm{L}^{-1}$. Com as condições já estabelecidas ou seja, primeiro a adição do ácido nítrico, em seguida o RETOTER sempre sob agitação mecânica constante, com aquecimento à temperatura de $90^{\circ} \mathrm{C}$ e mantendo-se por 3 horas de digestão. No total foram obtidos aproximadamente $2800 \mathrm{~mL}$ de nitrato de tório impuro (solução estoque). Depois partiu-se para a separação seletiva de rádio, tório, e de terras raras. 
Muitos ensaios preliminares foram realizados utilizando-se esta solução estoque de alimentação até a seleção dos parâmetros para o estabelecimento da metodologia descrita abaixo. Os ensaios foram realizados com muita cautela e observação para a definição desta metologia.

Primeiro foram encaminhadas duas amostras de RETOTER, nas condições originais, para o Centro de Metrologia das Radiações/Laboratório de Radiometria Ambiental (CMR/LRA) do IPEN/CNEN-SP.

As amostras de RETOTER homogeneizadas representativas do lote solução estoque foram analisadas por espectrometria gama. Os resultados foram imprecisos e não confiáveis, devido à alta concentração dos radionuclídeos e das impurezas existentes. Então foi necessário diluir as amostras. Descreve-se abaixo o procedimento da diluição da amostra representativa do lote de RETOTER para análise no Laboratório de Radiometria Ambiental.

\subsection{1 - Procedimento}

Retiraram-se $10 \mathrm{~g}$ de RETOTER e adicionaram-se em $50 \mathrm{~mL}$ de $\mathrm{HNO}_{3}$ na concentração de 4 mol. L ${ }^{-1}$ em um becker, com agitação magnética. Deixou-se em digestão durante 3 horas à temperatura de $80^{\circ} \mathrm{C}$ e o volume final foi de 40 $\mathrm{mL}$. Depois se completou o volume da solução para 1 litro, diluindo-se com água. Esta amostra foi encaminhada para o laboratório LRA para análise do rádio e de outros elementos radioativos. Pela análise de espectrometria gama da amostra de RETOTER, obteve-se o espectro da (FIG. 5.4) e a (TAB. 5.4) que se encontram no capítulo 5.

\section{5 - Experimentos preliminares para a precipitação do sulfato de bário (rádio)}

Utilizou-se a solução de nitrato de tório impuro do experimento 10. Este experimento foi obtido nos estudos de dissolução nítrica, trabalhando-se com relação 1:5 (massa de RETOTER por volume de ácido nítrico). Retiraram-se 31 $\mathrm{mL}$ dessa solução de nitrato de tório impuro e adicionaram-se $5 \mathrm{~mL}$ de nitrato de 
bário na concentração de 1 mol.L ${ }^{-1}$ e agitou-se por alguns minutos. Observou-se uma turvação. Depois adicionaram-se $5 \mathrm{~mL}$ de sulfato de amônio na concentração de $20 \%$ para formação do precipitado de sulfato de bário(rádio) e tornou-se a agitar por 10 minutos. Houve então a formação do precipitado fino, cristalino e branco. Fez-se a filtração em papel de filtro e o filtrado apresentou-se límpido. $O$ precipitado de sulfato de bário(rádio) foi lavado com água levemente acidulada. A massa do precipitado úmido obtido foi de 0,519 gramas.

Fez-se análise por espectrometria gama (Nal) das frações obtidas no experimento acima. Os espectros se encontram nas figuras: 5.5.1.1: amostra original 1 (nitrato de tório impuro); 5.5.1.2 sulfato de bário(rádio); 5.5.1.3 filtrado do precipitado; 5.5.1.4 água de lavagem; 5.5.1.4ª́gua de lavagem. Na figura 5.5.1.5 tem-se o espectro do sulfato de bário(rádio) por espectrometria gama com o detector de germânio. Os resultados e os espectros encontram-se no capítulo 5.

\section{6 - Metodologia estabelecida para a precipitação do sulfato de bário(rádio)}

Após a realização de vários experimentos no laboratório de processos químicos do CQMA estabeleceu-se a metodologia descrita a seguir.

$\mathrm{Na}$ solução de nitratos de tório, de terras raras, e impurezas obtidas da dissolução do RETOTER, separam-se o rádio, o tório e as terras raras.

\subsection{1 - Precipitação do sulfato de bário (rádio)}

Separou-se uma amostra de $100 \mathrm{~mL}$ da solução estoque e com agitação constante aqueceu-se a solução a uma temperatura próxima de $65^{\circ} \mathrm{C}$. Depois adicionaram-se $10 \mathrm{~mL}$ de nitrato de bário $1 \mathrm{~mol}$. $\mathrm{L}^{-1}$ para agir como carregador do rádio na precipitação do sulfato de bário. Deixou-se sob agitação magnética e com aquecimento por um tempo aproximado de 10 minutos, e depois iniciou-se a adição do sulfato de amônio. O aquecimento da solução e o meio nítrico são condições favoráveis para manterem o tório solúvel na solução ${ }^{[34]}$. 
A concentração da solução de sulfato de amônio foi de $20 \%$ tendo sido adicionado um total $16 \mathrm{~mL}$ parceladamente: 10,5 e $1 \mathrm{~mL}$. Depois deixou se sob agitação magnética e aquecimento por mais 20 minutos.

Observou-se que quando se adicionou o sulfato de amônio nada aconteceu de imediato, só depois de alguns segundos a solução começou a turvar, até que se formou um precipitado fino, cristalino e branco.

Desligou-se a agitação magnética e o aquecimento e deixou-se em repouso por 24 horas porque com o repouso a formação dos cristais é melhor $^{[35]}$. No dia seguinte o sobrenadante apresentava-se com aspecto límpido e transparente, com coloração levemente verde e o precipitado branco encontravase sedimentado no fundo do recipiente.

Fez-se teste com sulfato de amônio no sobrenadante para verificar se ainda ocorria precipitação de material, mas o resultado foi negativo.

O teste é feito da seguinte forma: deixa-se a solução em repouso até que o precipitado sedimente. Depois se retira uma alíquota do sobrenadante e adicionase em um tubo de ensaio e em seguida goteja-se a solução de sulfato de amônio sob agitação. Caso se forme precipitado continua-se adicionando o reagente na solução até que o resultado do teste seja negativo.

\subsection{2 - Filtração do sulfato de bário(rádio).}

A filtração foi realizada com papel de filtro para sólidos finos (faixa azul). 0 tempo de filtração foi de aproximadamente 27 horas. Depois realizou-se a operação de lavagem do precipitado.

\subsection{3 - Lavagem do precipitado de sulfato bário(rádio)}

Fez-se uma lavagem do precipitado de sulfato de bário(rádio) com solução de sulfato de amônio 20\%. Foi utilizado na lavagem um volume de $10 \mathrm{~mL}$ e depois juntou-se a água de lavagem do filtrado evitando-se assim perdas. Faz-se a lavagem do precipitado para retirar o tório e as terras raras solúveis que ficaram 
adsorvidas nele. Massa úmida obtida de sulfato de bário (rádio) igual a 1,6 gramas.

Primeiro fez-se uma análise qualitativa por espectrometria gama da amostra sólida de 1,6 g sulfato bário(rádio) tendo sido identificados o rádio e outros radionuclídeos. Então partiu-se para uma análise mais detalhada, onde teve-se a necessidade de dissolver a amostra de sulfato de bário(rádio) para se obter os resultados quantitativos. Para se determinar o background do aparelho fez-se uma análise apenas com água.

A dissolução foi preparada conforme os parâmetros sugeridos na literatura para a dissolução do sulfato de bário(rádio) ${ }^{[36]}$.

\subsection{4 - Procedimento para dissolução do sulfato de bário(rádio)}

A alíquota com 1,6 gramas de sulfato de bário(rádio) úmido, foi tratado com $80 \mathrm{~mL}$ de EDTA de $66,66 \mathrm{~g} \cdot \mathrm{L}^{-1}, 15 \mathrm{~mL}$ de $\mathrm{NH}_{4} \mathrm{OH}$ concentrado e aquecido à temperatura de $70^{\circ} \mathrm{C}$ em banho-maria. A amostra solubilizou totalmente. Depois completou-se o volume para $100 \mathrm{~mL}$ com água desionizada e encaminhou-se para o laboratório LRA. Para a análise espectrométrica a amostra precisa estar em uma geometria adequada. Para isso a amostra foi completada a $100 \mathrm{~mL}$ e colocada em frasco de polietileno padrão.

O espectro correspondente e resultados da análise estão na (FIG. 5.5.3) e (TAB. 5.5.3), vide capítulo 5.

Pode-se ver na FIG. 4.6.1 os precipitados de sulfato de bário(rádio). 


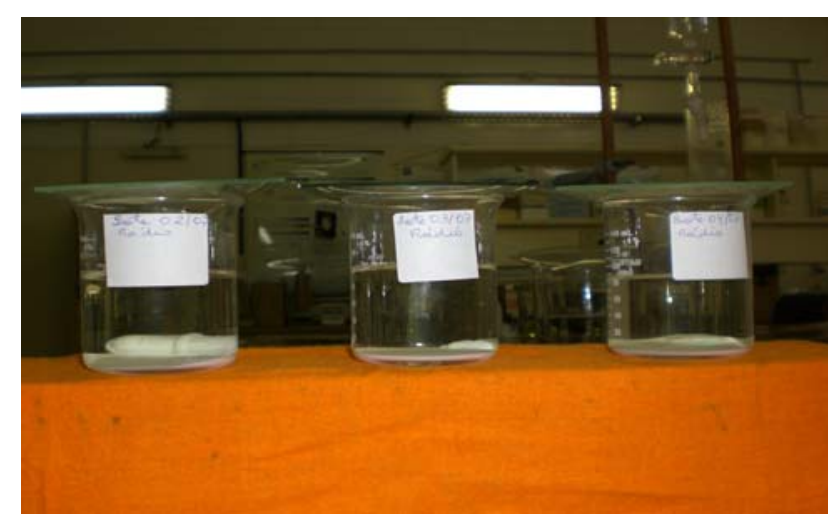

FIGURA 4.6.1 - Amostras do sulfato de bário(rádio)

Efetuaram-se mais três experimentos identificados como Lotes 02, 03, e 04. Repetiram-se os mesmos procedimentos e as mesmas condições de trabalho adotadas neste capítulo nos itens: 4.6.1; 4.6.2; 4.6.3. Fizeram-se os testes para saber se todos os precipitados haviam se formado bem e como os resultados foram negativos encerraram- se, então as adições de sulfato de amônio. Depois de repouso de 48 horas fizeram-se as filtrações com papel de filtro faixa azul. $\mathrm{Na}$ TAB. 4.6.1 estão as condições experimentais para a precipitação do $\mathrm{BaSO}_{4}(\mathrm{Ra})$.

TABELA 4.6.1 - Obtenção do sulfato de bário(rádio) dos lotes 02, 03 e 04.

\begin{tabular}{cccccc}
\hline Experimento & $\begin{array}{c}\text { Nitrato } \\
\text { de bário } \\
1 \mathrm{~mol}^{-1} \\
(\mathrm{~mL})\end{array}$ & $\begin{array}{c}\text { Sulfato de } \\
\text { amônio } \\
20 \%(\mathrm{~mL})\end{array}$ & $\begin{array}{c}\text { Volume } \\
\text { do filtrado } \\
(\mathrm{mL})\end{array}$ & $\begin{array}{c}\text { Tempo } \\
\text { de } \\
\text { filtração } \\
\text { ( horas })\end{array}$ & $\begin{array}{c}\text { Precipitado de } \\
\text { sulfato de } \\
\text { bário(rádio) úmido } \\
(\mathrm{g})\end{array}$ \\
\hline Lote 02 & 10 & 16 & 100 & 6 & 2,2 \\
Lote 03 & 10 & 16 & 100 & 6 & 2,1 \\
Lote 04 & 10 & 16 & 80 & 6 & 2,7 \\
\hline
\end{tabular}

Lavagem do precipitado de sulfato de bário(rádio) dos lotes 02, 03 e 04.

Lavaram-se os precipitados de sulfato de bário(rádio) com $10 \mathrm{~mL}$ de solução de sulfato de amônio $20 \%$ e juntaram-se as águas de lavagem aos filtrados.

\section{7 - Precipitação do Peróxido de Tório}

O filtrado da precipitação do sulfato de bário(rádio) encontrava-se ácido e para fazer a separação do tório via peróxido de hidrogênio tem-se a necessidade 
de elevar o pH. Então utilizou-se uma solução de hidróxido de amônio para esta finalidade.

Foram adicionados $45 \mathrm{~mL}$ de hidróxido de amônio na concentração de $19,8 \%$ em pequenos volumes até atingir pH 2,0. Evitou-se uma elevação maior do $\mathrm{pH}$, para não precipitar os hidróxidos de Th e TR.

Fez-se depois a precipitação do tório com peróxido de hidrogênio. Usou-se o filtrado gerado na precipitação do sulfato de bário (rádio) que era de $149 \mathrm{~mL}$ e adicionaram-se $13 \mathrm{~mL}$ e depois mais $3 \mathrm{~mL}$ de peróxido de hidrogênio a $30 \% \mathrm{v} / \mathrm{v}$. A adição foi feita gradativamente à temperatura ambiente e com agitação mecânica constante. Durante as adições do peróxido de hidrogênio, foram feitos os testes para saber se o tório havia sido totalmente precipitado.

Quando se inicia a adição o peróxido de hidrogênio imediatamente começa a precipitação do peróxido de tório. Utilizaram-se no total $26 \mathrm{~mL}$ peróxido de hidrogênio que foram adicionados da seguinte maneira: 13, 3, 4, 2, 2 e $2 \mathrm{~mL}$. As adições foram realizadas com o acompanhamento do teste para saber se ainda estava precipitando o peróxido de tório e cessou-se a adição quando não houve mais formação de precipitado.

\section{Teste para saber se a precipitação do peróxido de tório foi total.}

O teste é feito da seguinte forma: deixa-se a mistura em repouso até que o precipitado sedimente. Depois retira-se uma alíquota do sobrenadante para um tubo de ensaio e goteja-se a solução de peróxido de hidrogênio e agita-se a mistura. Havendo formação de precipitado continua-se adicionando o peróxido de hidrogênio até que a precipitação do tório seja finalizada.

\subsection{1 - Filtração do peróxido de tório}

Obteve-se um volume de filtrado de $175 \mathrm{~mL}$ na precipitação do peróxido de tório. A filtração foi realizada com papel de filtro faixa azul. O tempo de filtração foi de aproximadamente 2 horas. Depois fez-se a lavagem do precipitado. 


\subsection{2 - Lavagem do precipitado de peróxido de tório}

Inicialmente lavou-se o peróxido de tório com água desionizada e depois com ácido nítrico $0,1 \mathrm{~mol} . \mathrm{L}^{-1}$. As lavagens foram realizadas da seguinte forma:

a - lavagem do precipitado com $60 \mathrm{~mL}$ de água desionizada.

Tempo de filtração aproximado de 20 minutos.

b - lavagem do precipitado com $40 \mathrm{~mL}$ de $\mathrm{HNO}_{3}$ 0,1 mol.L ${ }^{-1}$.

Tempo de filtração aproximado de 20 minutos.

As lavagens são necessárias para retirar os elementos solúveis que ficaram retidos no precipitado. Peso do peróxido de tório úmido obtido igual a 5,1 gramas. Juntaram-se as águas de lavagem ao filtrado do peróxido de tório para evitar ao máximo as perdas.

\subsection{3 - Dissolução do peróxido de tório úmido}

Para a realização da análise por espectrometria gama dissolveu-se a amostra e utilizaram-se $100 \mathrm{~mL}$ de solução. Para a dissolução do peróxido utilizou-se ácido nítrico $7 \mathrm{~mol} . \mathrm{L}^{-1}$, cujo volume foi de $70 \mathrm{~mL}$. Depois adicionaramse $10 \mathrm{~mL}$ de água desionizada. Aqueceu-se para completar a solubilização. Com o aquecimento houve a mudança de cor de alaranjada para incolor, ocorrendo solubilização completa. No final completou-se o volume para $100 \mathrm{~mL}$ com água desionizada.

Com a análise da solução de dissolução do peróxido de tório obteve-se o espectro da FIG.5.6 e os resultados da TAB. 5.6, que se encontram no capítulo 5.

Amostras dos precipitados dos peróxidos de tório podem ser vistos na (FIG. 4.7). 


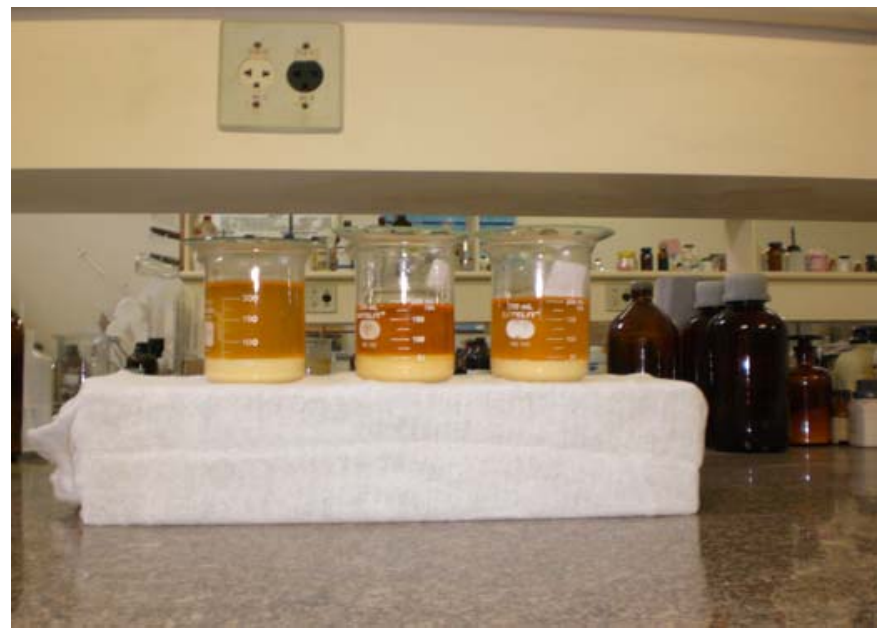

FIGURA 4.7 - Amostras de peróxido de tório

Prosseguindo-se com os experimentos dos lotes 02, 03 e 04 fez-se a precipitação do peróxido de tório.

Ajustou-se o pH das soluções com hidróxido de amônio 1:1 para depois realizar a precipitação do peróxido de tório. Durante a elevação do $\mathrm{pH}$ houve início de formação de precipitados nos lotes 03 e 04. Adicionou-se ácido nítrico diluído para dissolver os precipitados. Depois adicionou-se hidróxido de amônio novamente para atingir $\mathrm{pH} 2,0$ e em seguida adicionou-se o peróxido de hidrogênio. As quantidades utilizadas estão na (TAB. 4.7.1).

TABELA - 4.7.1 Massas de peróxido de tório e quantidades de reagentes utilizados.

\begin{tabular}{|c|c|c|c|c|c|c|}
\hline Experimento & $\begin{array}{c}\text { Hidróxido } \\
\text { de } \\
\text { amônio } \\
1: 1 \\
(\mathrm{~mL}) \\
\end{array}$ & $\mathrm{pH}$ & $\begin{array}{c}\text { Peróxido de } \\
\text { hidrogênio } \\
30 \% \text { v/v } \\
(\mathrm{mL})\end{array}$ & $\begin{array}{l}\text { Volume } \\
\text { do } \\
\text { filtrado } \\
\text { (mL) }\end{array}$ & $\begin{array}{l}\text { Massa de } \\
\text { peróxido de } \\
\text { tório úmida } \\
\text { (g) }\end{array}$ & $\begin{array}{c}\text { Tempo } \\
\text { de } \\
\text { filtração } \\
\text { ( horas ) }\end{array}$ \\
\hline Lote 02 & 82,5 & 2,0 & 26 & 194 & 9,0 & 3 \\
\hline Lote 03 & 77,5 & 2,5 & 30 & 205 & 9,4 & 3 \\
\hline Lote 04 & 80,0 & 2,0 & 30 & 205 & 7,8 & 3 \\
\hline
\end{tabular}

As lavagens do peróxido de tório foram realizadas em duas vezes. Uma com água desionizada e a outra com solução ácida diluída. Os valores estão na (TAB.4.7.2). 
TABELA - 4.7.2 Volumes de soluções de lavagens utilizadas.

\begin{tabular}{ccccc}
\hline Experimento & $\begin{array}{c}\text { Água } \\
\text { desionizada } \\
(\mathrm{mL})\end{array}$ & $\begin{array}{c}\text { Ácido nítrico } \\
0,1 \mathrm{~mol}^{-1} \\
(\mathrm{~mL})\end{array}$ & $\begin{array}{c}\text { Volume do } \\
\text { filtrado } \\
(\mathrm{mL})\end{array}$ & $\begin{array}{c}\text { Tempo de } \\
\text { filtração } \\
(\text { horas })\end{array}$ \\
\hline Lote 02 & 60 & 40 & 275 & 3 \\
Lote 03 & 60 & 40 & 318 & 3 \\
Lote 04 & 60 & 40 & 275 & 3 \\
\hline
\end{tabular}

\section{8 - Experimentos Exploratórios de Precipitação do Carbonato de Terras} Raras

Para a recuperação das terras raras utilizou-se uma solução de carbonato de sódio de concentração $1 \mathrm{~mol} . \mathrm{L}^{-1}$. Ao filtrado gerado na precipitação do peróxido de tório, juntou-se as águas de lavagem do peróxido e adicionou-se 45 $\mathrm{mL}$ de solução de carbonato de sódio. Fez-se a adição gradativamente à temperatura ambiente e com agitação magnética constante. Adicionaram-se duas frações de carbonato de sódio uma de $25 \mathrm{~mL}$ e a outra de $20 \mathrm{~mL}$.

Após a formação do precipitado a suspensão apresentou uma coloração levemente alaranjada. Fez-se o teste para saber se a precipitação das terras raras tinha finalizado.

O teste é feito da seguinte forma: deixa-se a mistura em repouso até que o precipitado sedimente. Depois retira-se uma alíquota do sobrenadante, adicionase em um tubo de ensaio e goteja-se a solução de carbonato de sódio e agita-se. Sendo necessário, adiciona-se mais carbonato até a precipitação completa das terras raras.

\subsection{1 - Filtração do carbonato de terras raras}

A filtração foi realizada em papel de filtro faixa azul. O tempo de filtração foi de aproximadamente 2 horas e $30 \mathrm{~min}$. O filtrado estava límpido e transparente. $\mathrm{O}$ volume do filtrado foi de $310 \mathrm{~mL}$ e $\mathrm{pH} 7,04$. Peso do carbonato de terras raras úmido igual a 6,3 gramas. 


\subsection{2 - Dissolução de carbonato de terras raras para a análise por espectrometria gama.}

Para a análise necessitou-se dissolver a amostra porque a geometria do aparelho utilizado é para um volume de $100 \mathrm{~mL}$ da amostra. Usaram-se $70 \mathrm{~mL}$ de ácido nítrico $7 \mathrm{~mol} . \mathrm{L}^{-1}$ para a dissolução total. Depois completou-se o volume com água desionizada para $100 \mathrm{~mL}$.

O espectro correspondente e os resultados estão na (FIG. 5.7) e (TAB. 5.7), no capítulo 5.

\section{9 - Precipitação do Peróxido de Terras Raras}

Estudou-se também a precipitação das terras raras com o peróxido de hidrogênio. Nos filtrados do peróxido de tório dos lotes 02, 03 e 04 adicionou-se hidróxido de amônio para o ajuste do pH próximo a 3. Adicionou-se o peróxido de hidrogênio a $30 \%$ v/v para a precipitação das terras raras como peróxidos. As adições da água oxigenada foram realizadas em duas frações. As quantidades utilizadas estão nas (TAB. 4.8.1 e TAB. 4.8.2).

TABELA - 4.8.1 Precipitação do peróxido de terras raras.

\begin{tabular}{ccccc}
\hline Experimento & $\begin{array}{c}\text { Volume de } \\
\mathrm{NH}_{4} \mathrm{OH} \mathrm{1:10} \\
(\mathrm{mL})\end{array}$ & $\begin{array}{c}\text { Volume de } \\
\mathrm{H}_{2} \mathrm{O}_{2} 30 \% \text { v/v } \\
(\mathrm{mL})\end{array}$ & $\begin{array}{c}\mathrm{pH} \text { inicial de } \\
\text { precipitação }\end{array}$ & $\begin{array}{c}\mathrm{pH} \text { final de } \\
\text { precipitação }\end{array}$ \\
\hline Lote 02 & 23,0 & 18 & 2,38 & 2,22 \\
Lote 03 & 24,5 & 23 & 3,13 & 2,11 \\
Lote 04 & 23,5 & 18 & 3,00 & 2,23 \\
\hline
\end{tabular}

Para saber se a precipitação do peróxido de TR foi completa tratou-se uma alíquota do filtrado com ácido oxálico. Sendo necessário faz-se nova adição de $\mathrm{H}_{2} \mathrm{O}_{2}$ e reajuste do $\mathrm{pH}$ com $\mathrm{NH}_{4} \mathrm{OH}$, pois pela reação da formação dos peróxidos de TR o pH diminui. As condições de precipitação dos peróxidos de terras raras estão na (TAB. 4.8.2). 
TABELA - 4.8.2. Massa de peróxido de terras raras em função das massas de reagente.

\begin{tabular}{|c|c|c|c|c|c|}
\hline Experimento & $\begin{array}{l}\mathrm{Vol} . \mathrm{H}_{2} \mathrm{O}_{2} \\
30 \% \mathrm{v} / \mathrm{v} \\
(\mathrm{mL})\end{array}$ & $\begin{array}{l}\mathrm{pH} \text { inicial de } \\
\text { precipitação }\end{array}$ & $\begin{array}{l}\mathrm{pH} \text { final de } \\
\text { precipitação }\end{array}$ & $\begin{array}{l}\text { Volume } \\
\text { de } \\
\text { filtrado } \\
(\mathrm{mL})\end{array}$ & $\begin{array}{l}\text { Massa de } \\
\text { peróxido de } \\
\text { terras raras } \\
\text { úmido } \\
\text { (g) }\end{array}$ \\
\hline Lote 02 & 15 & 3,9 & 2,57 & 255 & 28,6 \\
\hline Lote 03 & 15 & 4,0 & 2,75 & 345 & 23,6 \\
\hline Lote 04 & 15 & 3,5 & 2,46 & 312 & 18,0 \\
\hline
\end{tabular}

\subsection{1 - Filtração do peróxido de terras raras}

A filtração foi realizada com papel de filtro faixa azul. O tempo de filtração foi de aproximadamente 1 hora e 30 minutos, 6 horas e 1 hora para os lotes 02 , 03 e 04 , respectivamente.

$\mathrm{Na}$ FIG. 4.9.1 apresenta-se algumas amostras dos precipitados de peróxidos de terras raras.

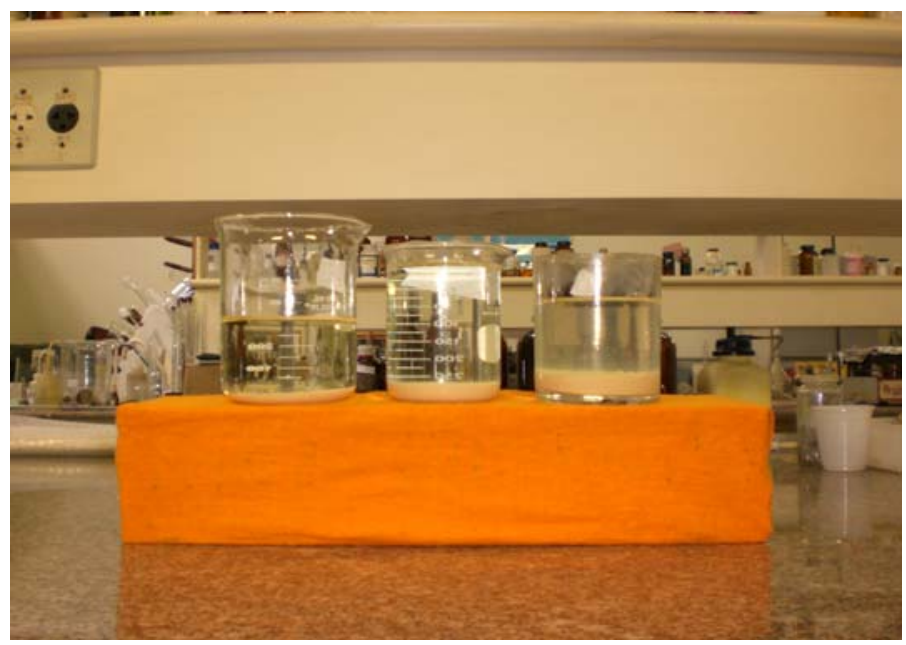

FIGURA - 4.9.1 Amostras de precipitados de peróxidos de terras raras 
4.9.2 - Dissolução do peróxido de terras raras para a análise por espectrometria gama.

Para a análise por espectrometria gama cada amostra de peróxido de terras raras foi dissolvida com $60 \mathrm{~mL}$ de $\mathrm{HNO}_{3} 4,5 \mathrm{~mol} . \mathrm{L}^{-1}$. O volume final foi ajustado com água desionizada para $100 \mathrm{~mL}$.

Na FIG. 4.9.2 tem-se as amostras das frações obtidas na separação seqüencial dos valores do RETOTER.

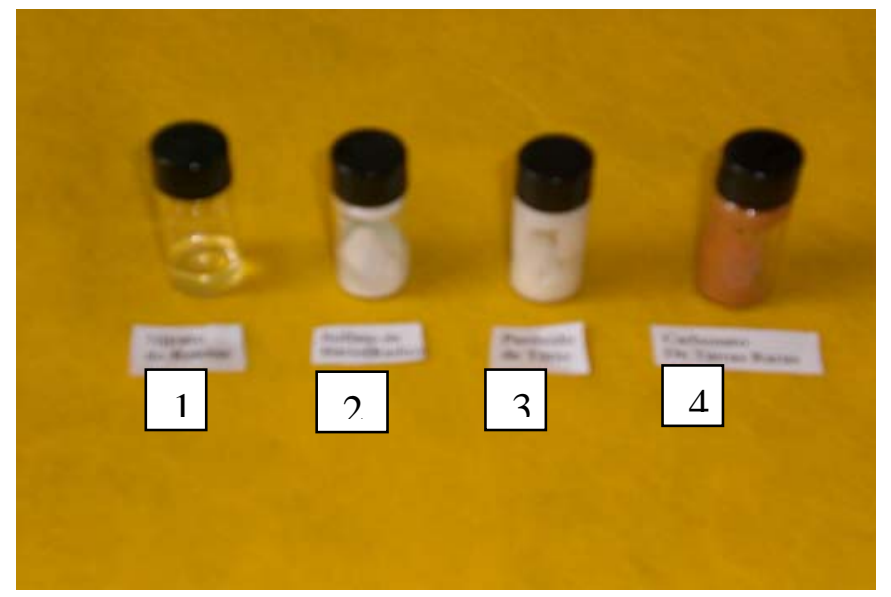

FIGURA - 4.9.2 Amostras das frações obtidas na separação seqüencial dos valores do RETOTER (1= Nitrato impuro, 2= $\mathrm{Ba}(\mathrm{Ra}) \mathrm{SO}_{4}, 3=$ Peróxido de Tório, 4= Peróxido de Terras Raras). 


\section{CAPÍTULO 5}

\section{RESULTADOS E DISCUSSÃO}

\section{1 - Resultados da dissolução nítrica do RETOTER}

De acordo com o capítulo 4.2 comenta-se sobre o objetivo de se estudar a melhor condição de dissolução do RETOTER, relacionando-se a sua massa com o volume de ácido nítrico necessário à sua dissolução ${ }^{[25]}$. Então, programaram-se os seguintes ensaios:

1 - experimentos com várias concentrações de ácido nítrico;

2 - experimentos variando-se as relações de massa de RETOTER por volume de ácido nítrico.

A metodologia considerada para a dissolução nítrica como modelo é a do experimento 10 descrito no item 4.2 do capitulo 4 .

\section{2- Determinação da concentração de tório e acidez livre}

Fez-se análise das soluções de nitrato de tório impuro para se determinar a concentração do tório e a acidez livre. Os resultados estão na (TAB. 5.2). Usou-se o procedimento analítico IPEN/QI-052 ${ }^{[29]}$. 
TABELA 5.2 - Determinações de acidez livre e das concentrações de tório nas soluções de nitrato bruto obtido pelo tratamento do RETOTER com ácido nítrico.

\begin{tabular}{ccccc}
\hline Experimento & $\begin{array}{c}\text { Concentração } \\
\text { de } \mathrm{HNO}_{3} \\
\left(\mathrm{~mol}^{-1}\right)^{-1}\end{array}$ & $\begin{array}{c}\text { Acidez livre } \\
\left(\mathrm{mol} . \mathrm{L}^{-1}\right)\end{array}$ & $\mathrm{pH}$ & $\begin{array}{c}\text { Concentração de } \mathrm{ThO}_{2} \\
(\mathrm{~g} / \mathrm{l})\end{array}$ \\
\hline 9 & 2 & 2,0 & 1,66 & 26,20 \\
10 & 4 & 4,8 & 1,34 & 24,02 \\
11 & 6 & 5,8 & 1,25 & 19,11 \\
12 & 8 & 7,0 & 1,10 & 16,93 \\
\hline
\end{tabular}

\section{3 - Resíduos}

Observou-se que em todos os experimentos não se conseguiu uma dissolução total do RETOTER. Os resíduos das filtrações de cada experimento foram secos a $150^{\circ} \mathrm{C}$ e depois calcinados a $843^{\circ} \mathrm{C}$ por um intervalo de tempo de duas horas. As massas finais estão na (TAB. 5.3).

Para $10 \mathrm{~g}$ de RETOTER úmido consideraram-se 6,82 gramas em água, portanto a massa inicial do RETOTER seco $=3,12$ gramas.

TABELA 5.3 - Estudo da quantidade de insolúveis nos experimentos de tratamento do RETOTER com ácido nítrico.

Relação 1:1

\begin{tabular}{cccc}
\hline Identificação & $\begin{array}{r}\text { Peso líquido inicial } \\
\text { da amostra }(\mathrm{g})\end{array}$ & $\begin{array}{c}\text { Peso líquido final } \\
\text { da amostra }(\mathrm{g})\end{array}$ & \% Resíduo \\
1 & 3,120 & 0,323 & 10,37 \\
2 & 3,120 & 0,124 & 3,96 \\
3 & 3,120 & 0,116 & 3,70 \\
4 & 3,120 & 0,165 & 5,30 \\
\hline
\end{tabular}


Relação 1:3

\begin{tabular}{cccc}
\hline Identificação & $\begin{array}{c}\text { Peso líquido inicial } \\
\text { da amostra }(\mathrm{g})\end{array}$ & $\begin{array}{c}\text { Peso líquido final } \\
\text { da amostra }(\mathrm{g})\end{array}$ & \% Resíduo \\
5 & 3,120 & 0,239 & 7,66 \\
6 & 3,120 & 0,107 & 3,43 \\
7 & 3,120 & 0,163 & 5,22 \\
8 & 3,120 & 0,147 & 4,68
\end{tabular}

Relação 1:5

\begin{tabular}{cccc}
9 & 3,120 & 0,222 & 7,13 \\
10 & 3,120 & 0,118 & 3,78 \\
11 & 3,120 & 0,169 & 5,42 \\
12 & 3,120 & 0,238 & 7,62 \\
\hline
\end{tabular}

As águas de lavagem dos resíduos apresentaram-se límpidas e incolores.

As filtrações das dissoluções dos experimentos com a concentração de ácido nítrico 2 mol. $\mathrm{L}^{-1}$ que são 1, 5, e 9 se mostraram ruins, pois foram lentas e passaram resíduos para os filtrados. Apesar de ter sido utilizado papel de filtro para reter as partículas finas, e sendo utilizado o mesmo tipo de papel em todas as filtrações dos experimentos realizados. As quantidades de insolúveis restantes foram altas $10,37,7,66$ e $7,13 \%$, respectivamente.

As filtrações das dissoluções 11 e 12 com proporções 1:5 foram ótimas porque foram rápidas ( aproximadamente 2 horas ) e eficientes, com os filtrados límpidos, porém com quantidades de resíduos maiores do que o 10. Os resíduos dos experimentos 9, 11, e 12 apresentaram uma coloração bege claro, e o 10 bege mais claro do que os outros.

Uma análise dos experimentos realizados permite afirmar que as melhores condições de dissolução do RETOTER é o do experimento 10, com ácido nítrico 4 mol. $L^{-1}$ e relação RETOTER/ácido nítrico 1:5. O tempo de filtração é aceitável e o 
resíduo foi de 3,78 \%. Tentou-se obter um máximo de dissolução do RETOTER, para melhor aproveitamento do tório e das terras raras nele contido, otimizandose o consumo de ácido e buscando condições práticas ideais, para a separação do tório como peróxido e das terras raras como um grupo de elementos na forma de peróxidos. Este, no final do trabalho, poderia também ser tratado para a separação individual dos elementos.

O tratamento do RETOTER com ácido nítrico é feito a quente. Na parte experimental procurou-se conhecer bem os parâmetros envolvidos, como concentração do ácido, temperatura, agitação, tempo de residência e filtração. $O$ tratamento do RETOTER com ácidos sempre deixa um resíduo.

\section{4 - Solução estoque de nitrato de tório e terras raras proveniente do RETOTER}

A solução estoque utilizada para a determinação dos parâmetros para o estabelecimento da metodologia descrita anteriormente no item 4.4 do capítulo 4 foi analisada e os resultados foram os seguintes: $28,2 \mathrm{~g} \cdot \mathrm{L}^{-1} \mathrm{emThO}_{2}, 4,4 \mathrm{~g} \cdot \mathrm{L}^{-1} \mathrm{em}$ óxidos de terras raras $\left(\mathrm{TR}_{2} \mathrm{O}_{3}\right)$ e acidez livre igual a $3,7 \mathrm{~mol} . \mathrm{L}^{-1}$.

As amostras escolhidas de RETOTER e homogeneizadas, representativas do lote, foram analisadas por espectrometria gama.

Os resultados foram imprecisos e não confiáveis, devido à alta concentração dos radionuclídeos e das impurezas nas soluções. Então foi necessário diluir as amostras. Descreveu-se no item 4.4 o procedimento da diluição da amostra representativa do lote de RETOTER para análise no LRA.

O Espectro de energia gama de uma solução obtida do RETOTER é mostrado na FIG. 5.4 e os resultados para os radionuclideos na (TAB. 5.4). 


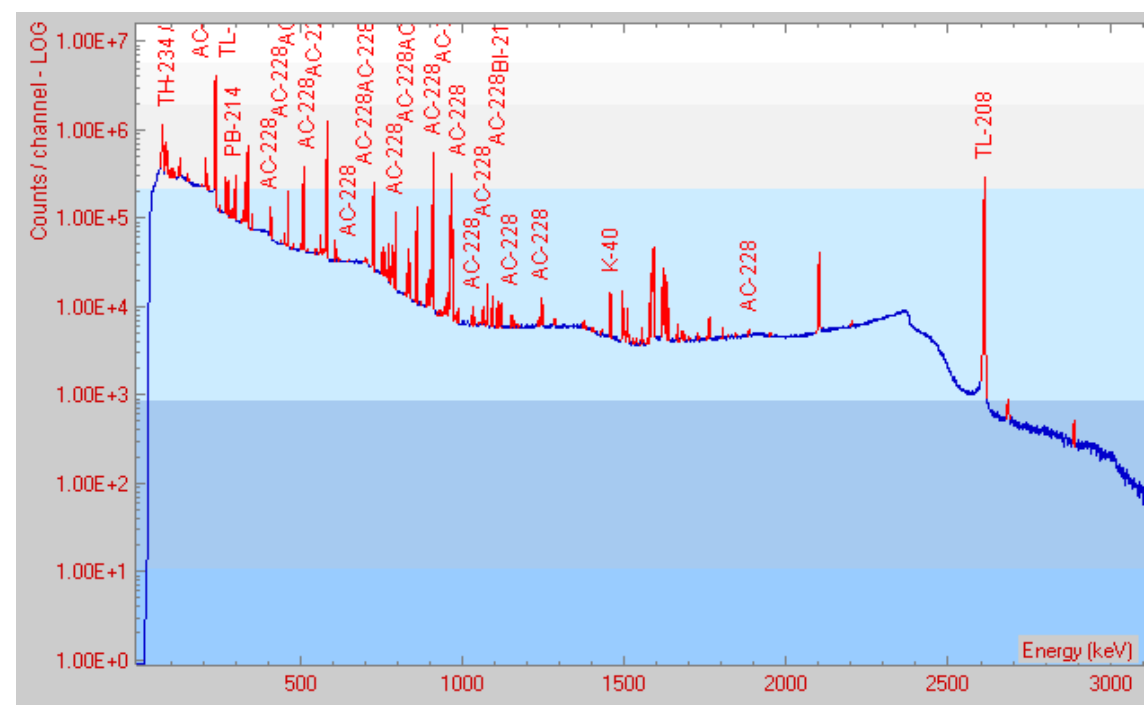

FIGURA 5.4 Espectro de energia gama de uma solução obtida da dissolução do RETOTER

TABELA 5.4 - Espectrometria gama (HPGe) do RETOTER

\begin{tabular}{lccccc}
\hline \multicolumn{5}{c}{ Atividade $\left(\mathrm{Bq}^{-1} \mathrm{~g}^{-1}\right)$} \\
\hline Amostra & ${ }^{228} \mathrm{Ra}$ & ${ }^{226} \mathrm{Ra}$ & ${ }^{210} \mathrm{~Pb}$ & ${ }^{238} \mathrm{U}$ & ${ }^{40} \mathrm{~K}$ \\
\hline RETOTER & $5675 \pm 4$ & $\mathrm{nd}$ & $\mathrm{nd}$ & $\mathrm{nd}$ & $165 \pm 5$ \\
\hline nd: não determinado & & & & &
\end{tabular}

Discussão

Observam-se várias energias do ${ }^{228} \mathrm{Ac}$ e ${ }^{40} \mathrm{~K}$. Então quantificou-se $\mathrm{o}{ }^{228} \mathrm{Ra}$ pelas energias de 911,07 e 968,90 kev do ${ }^{228}$ Ac que é o seu nuclídeo filho proveniente da série de decaimento natural do ${ }^{232} \mathrm{Th}$, então foi quantificado como $5.675 \mathrm{~Bq} . \mathrm{g}^{-1}$ e o ${ }^{40} \mathrm{k}$ foi quantificado pela energia de $1.460,83 \mathrm{kev}$ dele próprio como sendo $165 \mathrm{~Bq} \cdot \mathrm{g}^{-1}$. Os nuclídeos ${ }^{226} \mathrm{Ra},{ }^{210} \mathrm{~Pb}$, e ${ }^{238} \mathrm{U}$ não foram determinados.

5.5 - Resultados dos experimentos de precipitação do sulfato de bário e coprecipitação do rádio

\subsection{1 - Precipitação do sulfato de bário(rádio)}

$\mathrm{Na}$ solução de nitratos de tório, de terras raras e impurezas obtidas da dissolução do RETOTER, separa-se o rádio utilizando-se o método da 
precipitação do sulfato de bário no qual o rádio é coprecipitado conforme procedimento descrito no item 4.5, no capítulo 4.

Na FIG. 5.5.1.1 tem-se o espectro de uma amostra da solução de tório e terras raras obtidos do RETOTER.

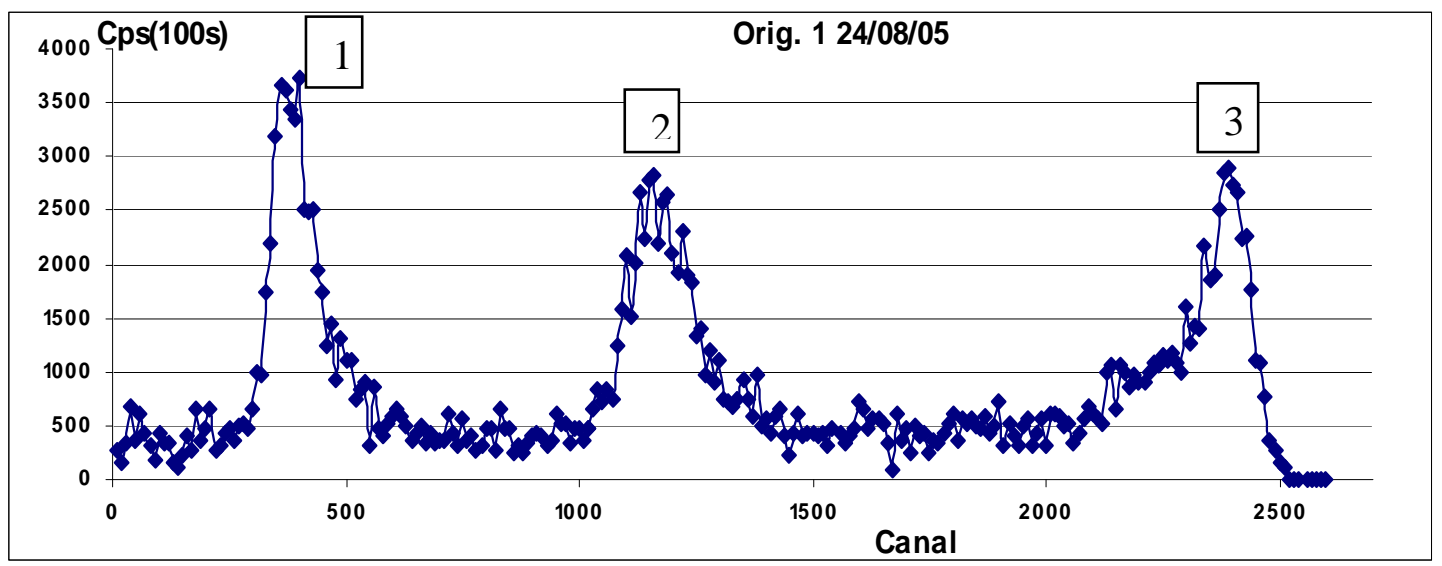

FIGURA 5.5.1.1. - Espectrometria gama (Nal) da amostra original 1 (nitrato de tório impuro), obtido da dissolução do RETOTER. Contagem 100 segundos.

Na FIG. 5.5.1.2 tem-se o espectro de um precipitado de $\mathrm{BaSO}_{4}(\mathrm{Ra})$ obtido da solução impura do RETOTER. Amostra=0,519g, contagem 100 segundos.

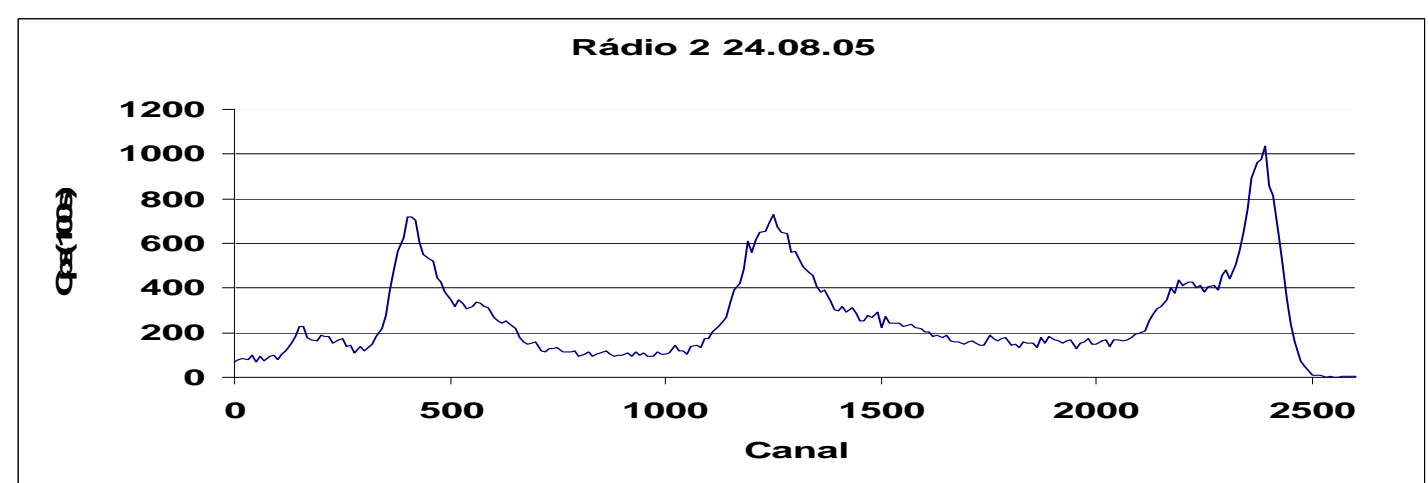

FIGURA 5.5.1.2 - Espectrometria gama (Nal) do sulfato de bário(rádio). 
Na FIG. 5.5.1.3 tem-se o espectro do filtrado do precipitado de sulfato de bário(rádio).

1

3

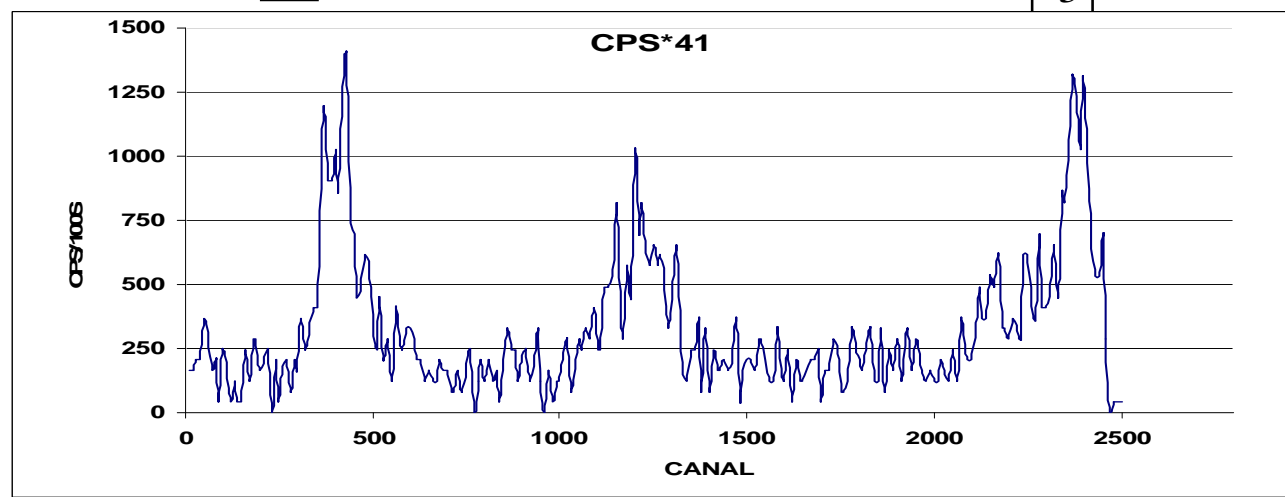

FIGURA 5.5.1.3 - Espectrometria gama (Nal) do filtrado do sulfato de bário(rádio). Contagem 100 segundos.

Na FIG. 5.5.1.4 tem-se o espectro da solução de lavagem do precipitado de sulfato de bário(rádio).

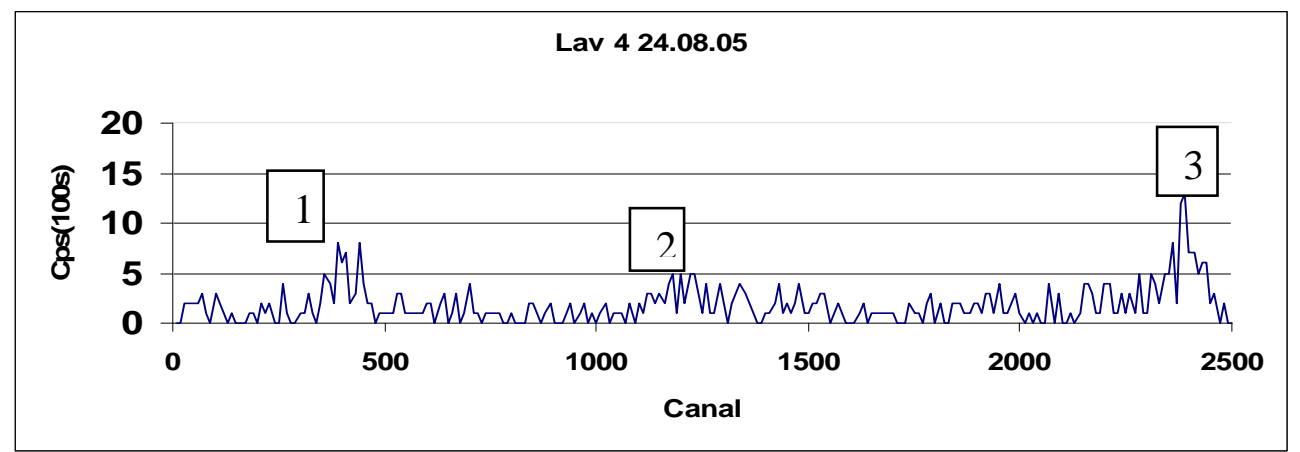

FIGURA 5.5.1.4 - Espectrometria gama (Nal) da água de lavagem do sulfato de bário(rádio). Contagem 100 segundos.

Na FIG. 5.5.1.4a tem-se o espectro de uma solução de lavagem do precipitado $\mathrm{BaSO}_{4}(\mathrm{Ra})$, mas com um tempo de contagem maior.

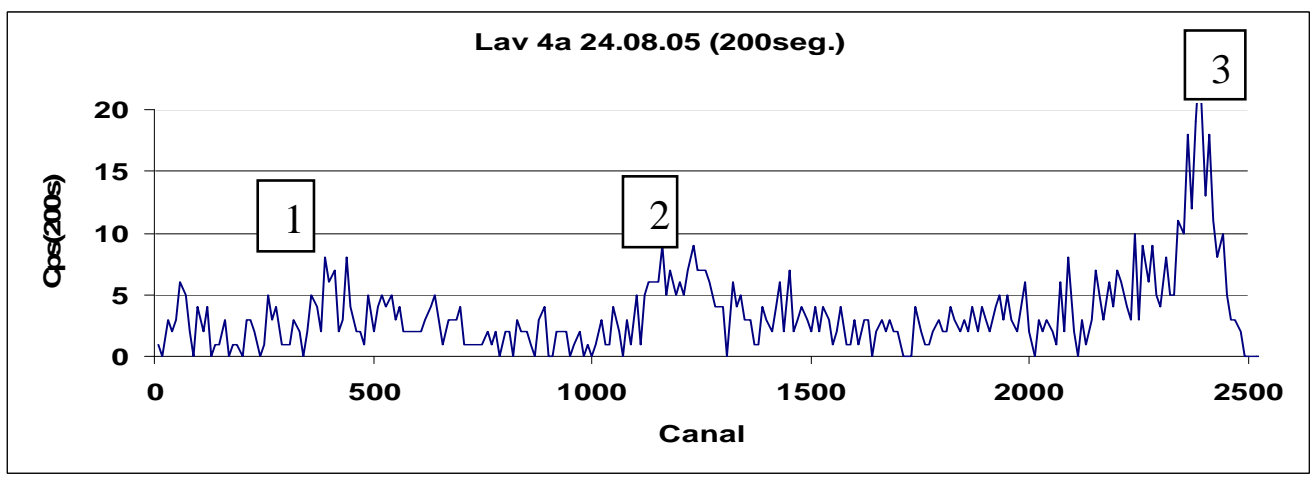

FIGURA 5.5.1.4a - Espectrometria gama (Nal) da água de lavagem 4a do sulfato de bário(rádio). Contagem 200 segundos. 


\section{Discussão}

Observou-se que os intervalos das escalas dos eixos cps(100s) variaram bastante de acordo com as desintegrações correspondentes de cada amostra. $\mathrm{Na}$ análise destes espectros (contagens $X$ canais) verificou-se que os picos 1,2 e 3 , apareceram em todas as amostras. Os picos foram caracterizados pelas energias encontradas nas tabelas. Portanto, no pico 1 identificam-se o $\mathrm{Th}^{228}$ e o $\mathrm{Rn}^{220}$. No pico 2 identificam-se os radioisótopos $\mathrm{Ra}^{228}$ na energia 238,6 kev com 64,9\% , o $\mathrm{Ra}^{224}$ na energia 238,6 kev com 43,6\% e o $\mathrm{Th}^{228}$ na energia de 238,6 kev com $12 \%$. No pico 3 identificam-se os seguintes radioisótopos $\mathrm{Tl}^{208}$ na energia 2614 kev com 99,8\%, o $\mathrm{Ra}^{228}$ na energia $911 \mathrm{kev}$ com 29\%, $\mathrm{Ra}^{228}$ na energia $968 \mathrm{kev}$ com $17 \%$ e o $\mathrm{Tl}^{208}$ na energia $860,4 \mathrm{kev}$ com $12 \%$. O intervalo de tempo de contagem para cada amostra foi de 100 segundos para os espetros das FIG. 5.5.1.1 - 5.5.1.4 e para a amostra da FIG. 5.5.1.4a foi de 200 segundos.

\section{Resultados e discussão}

Estudou-se a dissolução do RETOTER, variando-se a relação massa/ volume sob agitação e aquecimento a $80^{\circ} \mathrm{C}$ e também a dissolução sobre material úmido e seco. Quando a dissolução é realizada sob material seco esta não é completa, restando uma grande quantidade de insolúveis. A melhor relação encontrada na dissolução foi de 1:5 (10 g de retoter úmido com $50 \mathrm{ml}$ de $\mathrm{HNO}_{3} 4$ mol. $\left.\mathrm{L}^{-1}\right)$, para que haja uma dissolução praticamente completa do material.

Na FIG. 5.5.1.5 apresenta-se a análise por espectrometria gama com detector de germânio do precipitado de sulfato de bário(rádio). Pode-se notar pelos picos de energia em 238,270 , e 338 , que houve a co-precipitação do rádio, como esperado. 


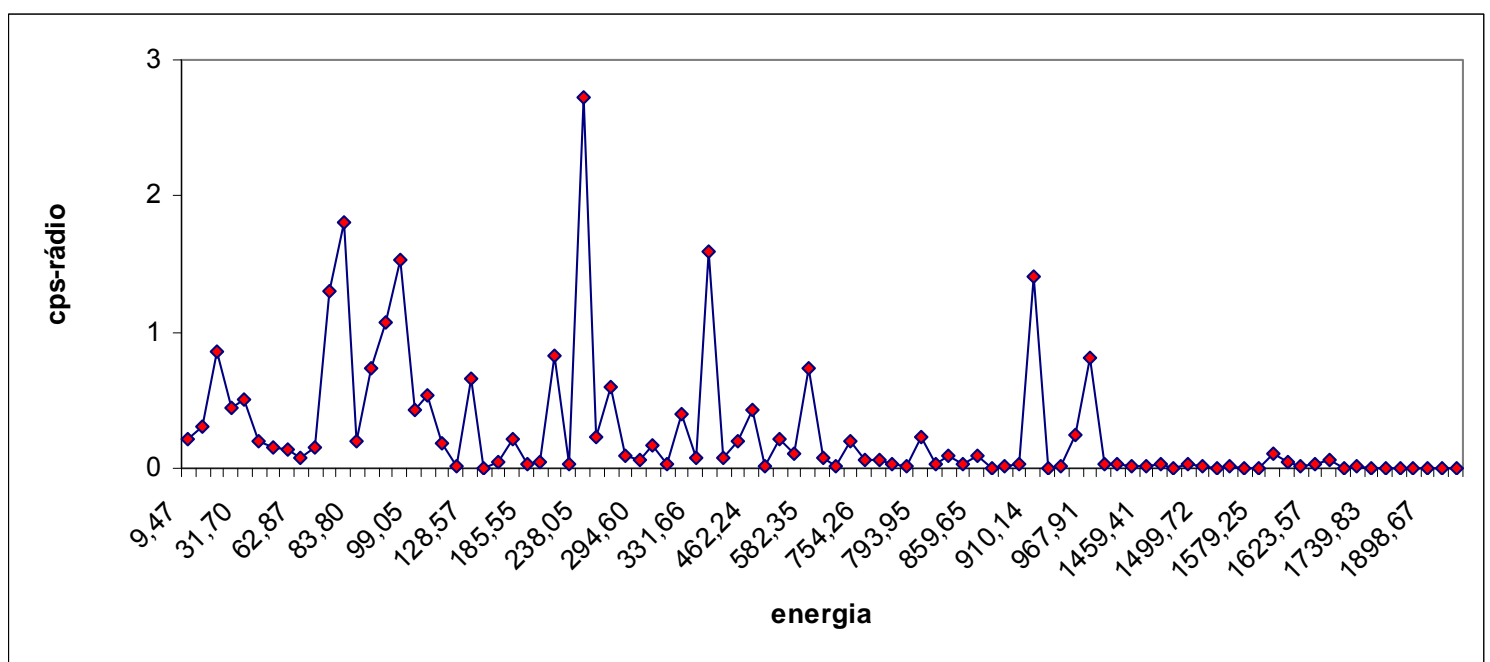

FIGURA 5.5.1.5 - Análise do sulfato de bário(rádio) por espectrometria gama com detector de germânio.

\subsection{2 - Resultados obtidos pela metodologia estabelecida para a precipitação do sulfato de bário(rádio)}

$\mathrm{Na}$ solução de nitratos de tório, de terras raras, e impurezas obtidas da dissolução do retoter, separa-se o rádio utilizando-se o método da precipitação do sulfato de bário no qual o rádio é coprecipitado.

Com esta finalidade separou-se uma amostra de $100 \mathrm{ml}$ de nitrato de tório impuro da dissolução do RETOTER conforme descrito no item 4.4, que se refere à solução estoque preparada para os experimentos.

\subsection{3 - Lavagem do precipitado de sulfato de bário(rádio)}

Fez-se uma lavagem com solução de sulfato de amônio $20 \%$ no precipitado de sulfato de bário(rádio), de acordo com o procedimento descrito no item 4.6.3, no capítulo 4.

O procedimento para dissolução do sulfato de bário(rádio) conforme item 4.6.4 no capítulo 4 . 
Para a análise espectrométrica a amostra precisa estar em uma geometria adequada. Para isso a amostra foi completada a $100 \mathrm{ml}$ e colocada em frasco de polietileno padrão.

Pela análise de espectrometria gama do sulfato de bário(rádio), obteve-se o espectro que é mostrado na FIG. 5.5.3 e também os resultados da análise que são apresentados na (TAB. 5.5.3).

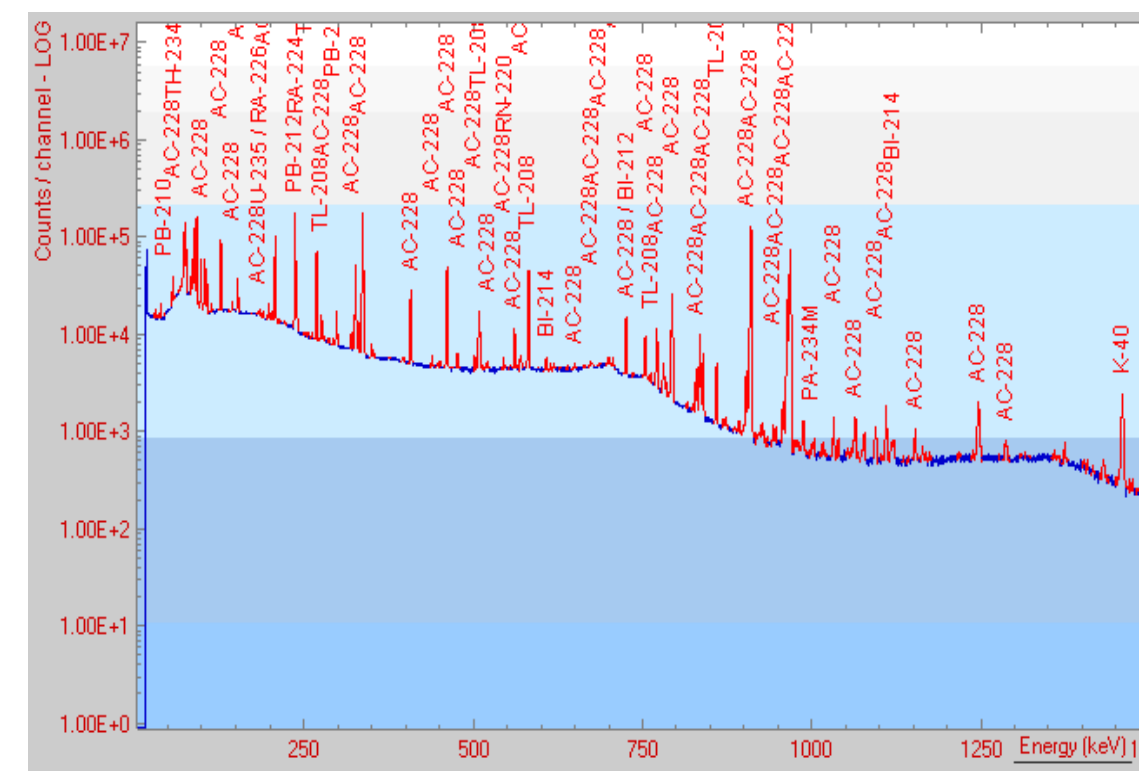

FIGURA 5.5.3 - Espectro do sulfato de bário (rádio)

TABELA 5.5.3 - Espectrometria gama (HPGe) da fração do $\mathrm{Ba}(\mathrm{Ra}) \mathrm{SO}_{4}$

\begin{tabular}{lccccc}
\hline \multicolumn{5}{c}{ Atividade $\left(\mathrm{Bq} \cdot \mathrm{g}^{-1}\right)$} \\
\hline Amostra & ${ }^{228} \mathrm{Ra}$ & ${ }^{226} \mathrm{Ra}$ & ${ }^{210} \mathrm{~Pb}$ & ${ }^{238} \mathrm{U}$ & ${ }^{40} \mathrm{~K}$ \\
\hline Sulfato de & $34520 \pm$ & $667 \pm$ & $38 \pm 9$ & $1229 \pm 140$ & $1344 \pm 54$ \\
Bário(Rádio) & 410 & 43 & $38 \pm 0$. \\
\hline
\end{tabular}

Observação: Por necessidade na espectrometria gama de $100 \mathrm{ml}$ resultante da dissolução do sulfato de bário teve-se que diluir para $500 \mathrm{ml}$ e depois contar os $100 \mathrm{ml}$.

Discussão

Pela metodologia estabelecida, observa-se a possibilidade de medir ${ }^{228} \mathrm{Ra}$, ${ }^{226} \mathrm{Ra},{ }^{210} \mathrm{~Pb},{ }^{238} \mathrm{U}$ e ${ }^{40} \mathrm{~K}$. O resultado obtido para $\mathrm{O}{ }^{228} \mathrm{Ra}$ foi de $34.520 \mathrm{~Bq} \cdot \mathrm{g}^{-1}$. Observaram-se praticamente todas as energias do ${ }^{228} \mathrm{Ac}$, possibilitando a 
quantificação do ${ }^{228} \mathrm{Ra}$. Observam-se as linhas do ${ }^{214} \mathrm{~Pb}$ e do ${ }^{214} \mathrm{Bi}$ possibilitando a quantificação do ${ }^{226} \mathrm{Ra}$. A amostra ficou lacrada por um período de 25 dias para atingir o equilíbrio entre ${ }^{226} \mathrm{Ra}$ e os filhos ${ }^{214} \mathrm{~Pb}$ e ${ }^{214} \mathrm{Bi}$ com meia vidas de 26,8 e 19,9 minutos, respectivamente. Observa-se também a energia de 46,54 kev do

${ }^{210} \mathrm{~Pb}$ (este medido direto). Observa-se ainda o fotopico correspondente ao ${ }^{234 \mathrm{~m}} \mathrm{~Pa}$ com meia vida 1,17 minutos. Isto garante a presença de ${ }^{238} \mathrm{U}$ em equilíbrio. $\mathrm{O}$ que possibilita quantificar $0{ }^{238} \mathrm{U}$ presente. Foi possível também medir $0{ }^{40} \mathrm{~K}$, por $1.460,83 \mathrm{kev}$.

\section{6 - Precipitação do peróxido de tório}

Do filtrado proveniente da coprecipitação do rádio fez-se a separação do tório por precipitação de seu peróxido, em meio levemente ácido, conforme já descrito no item 4.7, no capitulo 4. Nesta condição, a separação é bem seletiva. Por exemplo, as terras raras não acompanham o tório no seu peróxido. A equipe do IPEN já tem bom conhecimento deste processo ${ }^{[9,10]}$.

O peróxido de tório é um produto altamente insolúvel. Pode ser transformado ao óxido $\mathrm{ThO}_{2}$ por calcinação. Pode também ser dissolvido com ácidos para obtenção de seus sais, por exemplo, o nitrato de tório.

O RETOTER usado para esta dissertação contém pequenos teores de urânio. O nitrato de uranilo também pode ser levado ao peróxido por adição de água oxigenada. $\mathrm{O}$ pH de precipitação do peróxido de urânio está em 2,5. Assim, o peróxido de urânio acompanha o tório ${ }^{[37]}$.

O estudo de separação destes pequenos teores de urânio será feito posteriormente. O objetivo mais urgente era a separação tório - terras raras urânio, reaproveitados do RETOTER. As demais impurezas deste resíduo ficam nos filtrados dos peróxidos. 


\subsection{1 - Filtração}

Conforme descrito no item 4.7.1 no capítulo 4.

\subsection{2 - Lavagem do peróxido de tório}

Conforme descrito no item 4.7.2 no capítulo 4.

As lavagens são necessárias para retirar os elementos solúveis que ficaram retidos no precipitado. Peso do peróxido de tório úmido $=5,1$ gramas. Juntaram-se as águas de lavagens com o filtrado do peróxido de tório para tentar evitar ao máximo as perdas.

Dissolução do peróxido de tório úmido: Conforme descrito no item 4.7.3 no capitulo 4. Pela análise do peróxido de tório obteve-se o espectro da (FIG. 5.6).

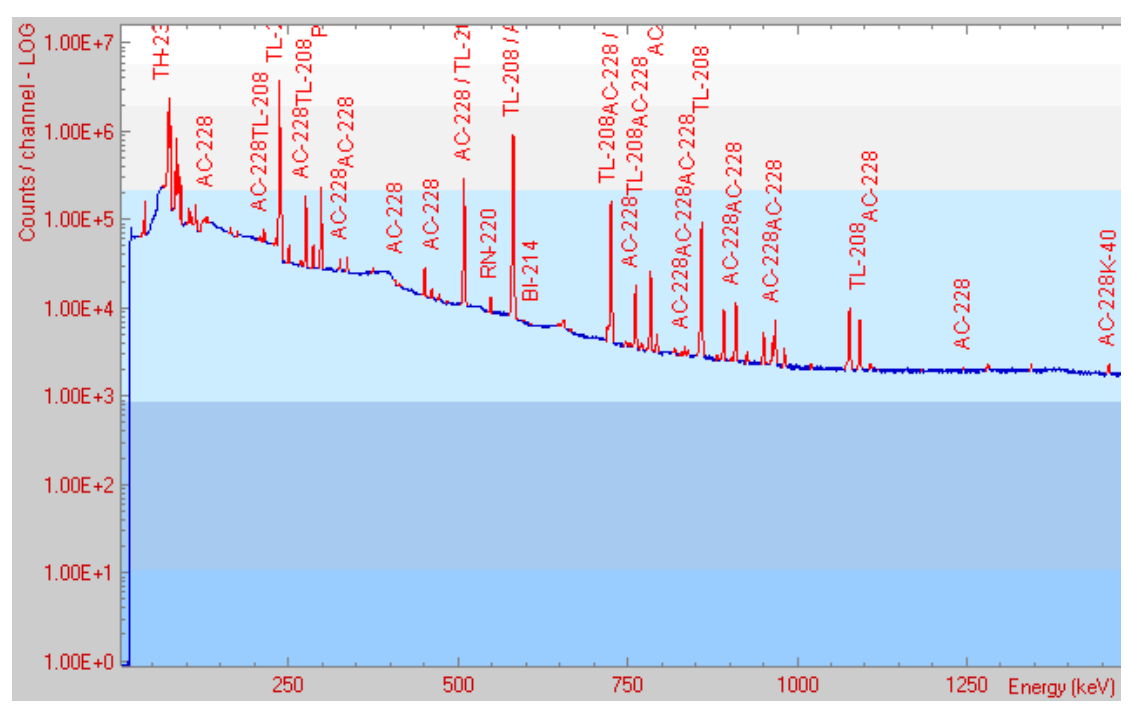

FIGURA 5.6 - Espectro do peróxido de tório

TABELA 5.6 - Espectrometria gama (HPGe) da fração peróxido de tório

\begin{tabular}{lccccc}
\hline \multicolumn{5}{c}{ Atividade $\left(\mathrm{Bq} . \mathrm{g}^{-1}\right)$} \\
\hline Amostra & ${ }^{228} \mathrm{Ra}$ & ${ }^{226} \mathrm{Ra}$ & ${ }^{210} \mathrm{~Pb}$ & ${ }^{238} \mathrm{U}$ & ${ }^{40} \mathrm{~K}$ \\
\hline Peróxido de tório & $194 \pm 8$ & nd & nd & nd & nd \\
\hline
\end{tabular}

nd: não determinado 
Discussão

Observaram-se as energias ${ }^{228} \mathrm{Ac}$, possibilitando a quantificação do ${ }^{228} \mathrm{Ra}$ presente. Verifica-se uma quantidade muito baixa do ${ }^{228} \mathrm{Ra}$, mostrando que foi separado na fração do sulfato de bário. Não foram detectados ${ }^{226} \mathrm{Ra},{ }^{210} \mathrm{~Pb},{ }^{238} \mathrm{U}$, e também ${ }^{40} \mathrm{~K}$. O ${ }^{230}$ Th também foi possível de se o observar com a separação do rádio, caso que antes não era.

\section{7 - Precipitação do carbonato de terras raras}

Separado o tório procurou-se ajustar uma tecnologia para a precipitação das terras raras. Inicialmente pensou-se em fazer uso da precipitação dos carbonatos, conforme descrito no item 4.8 no capitulo 4. Experimentos preliminares indicaram que esta tecnologia poderia ser aplicada. Porém, considerando-se que o filtrado do peróxido de tório tem excesso de água oxigenada, resolveu-se estudar a precipitação das terras raras como peróxido, numa operação seqüencial à separação do tório.

Os peróxidos de terras raras também podem ser levados aos óxidos correspondentes por calcinação ou então, como para o tório, podem ser dissolvidos com ácidos para a preparação dos correspondentes sais.

\subsection{1 - Filtração}

Conforme descrito no item 4.8.1 no capítulo 4.

\subsection{2 - Dissolução de carbonato úmido de terras para a análise de espectrometria gama.}

Conforme descrito no item 4.8 .2 no capítulo 4. 
Pela análise do carbonato de terras raras obteve-se o espectro da (FIG. $5.7)$.

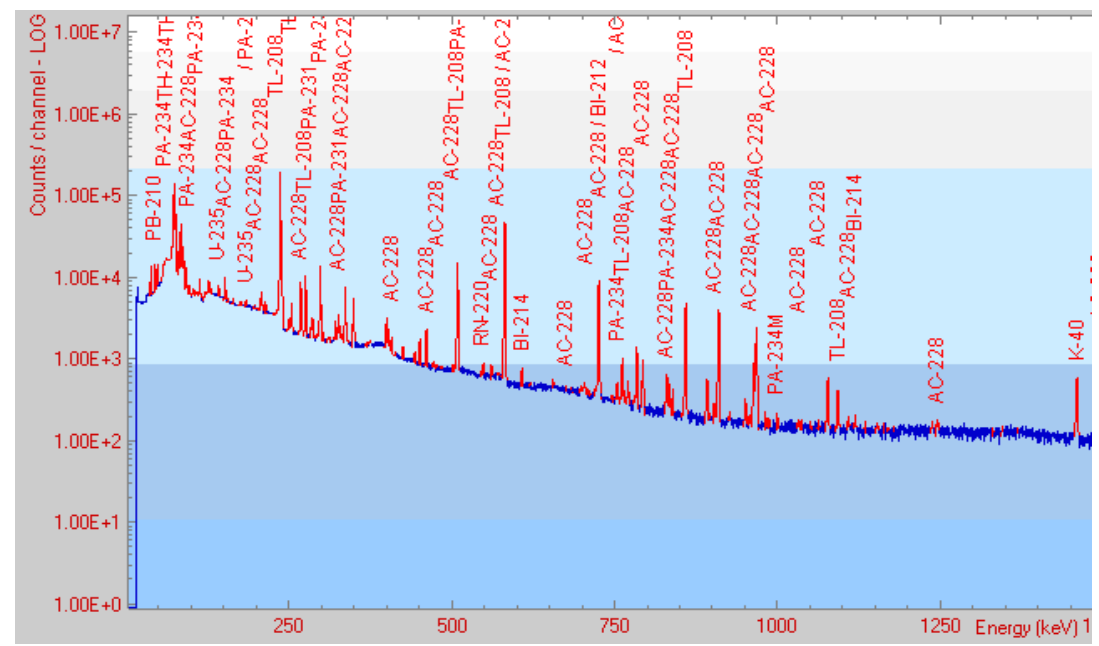

Figura 5.7 - Espectro do carbonato de terras raras

TABELA 5.7 - Espectrometria gama (HPGe) da fração de carbonato de terras raras.

\begin{tabular}{|c|c|c|c|c|c|}
\hline & \multicolumn{5}{|c|}{ Atividade (Bq. $\left.\mathrm{g}^{-1}\right)$} \\
\hline Amostra & ${ }^{228} \mathrm{Ra}$ & ${ }^{226} \mathrm{Ra}$ & ${ }^{210} \mathrm{~Pb}$ & ${ }^{238} \mathrm{U}$ & ${ }^{40} \mathrm{~K}$ \\
\hline $\begin{array}{l}\text { Carbonato de } \\
\text { terras raras }\end{array}$ & $407 \pm 5$ & nd & $\begin{array}{c}208 \pm \\
10\end{array}$ & $107 \pm 26$ & $16 \pm 3$ \\
\hline
\end{tabular}

Discussão

Foi possível quantificar o ${ }^{228} \mathrm{Ra}$ como $407 \mathrm{~Bq} \cdot \mathrm{g}^{-1}, \mathrm{o}{ }^{210} \mathrm{~Pb}$ como $208 \mathrm{~Bq} \cdot \mathrm{g}^{-1}$, o ${ }^{238} \mathrm{U}$ como $107 \mathrm{~Bq} \cdot \mathrm{g}^{-1}$ e o ${ }^{20} \mathrm{~K}$ como $16 \mathrm{~Bq} \cdot \mathrm{g}^{-1}$, nesta fração de terras raras. Observa-se que o ${ }^{228} \mathrm{Ra}$ foi quantificado como $407 \mathrm{~Bq} \cdot \mathrm{g}^{-1}$ e equivale a $1,2 \%$ do ${ }^{228} \mathrm{Ra}$ presente no sulfato de bário(rádio). Mostrando a efetividade da separação seletiva estabelecida. 


\section{CAPÍTULO 6}

\section{CONCLUSÃO}

O tratamento do RETOTER com ácido nítrico é feito a quente. Na parte experimental procurou-se conhecer bem os parâmetros envolvidos, como concentração do ácido, temperatura, agitação, tempo de residência e filtração. $O$ tratamento do RETOTER com ácidos sempre deixa um resíduo.

Feita a lixiviação do tório e terras raras no RETOTER fez-se a separação do tório por precipitação de seu peróxido, em meio levemente ácido. Nesta condição, a separação é bem seletiva. Por exemplo, as terras raras não acompanham o tório no seu peróxido. A equipe do IPEN já tem bom conhecimento deste processo ${ }^{[9,10]}$.

O peróxido de tório é um produto altamente insolúvel. Pode ser transformado ao óxido $\mathrm{ThO}_{2}$ por calcinação. Pode também ser dissolvido com ácidos para obtenção de seus sais, por exemplo, o nitrato de tório.

Separado o tório procurou-se ajustar uma tecnologia para a precipitação das terras raras. Inicialmente pensou-se em fazer uso da precipitação dos carbonatos. Experimentos preliminares indicaram que esta tecnologia poderia ser aplicada. Porém, considerando-se que o filtrado do peróxido de tório tem excesso de água oxigenada, resolveu-se estudar a precipitação das terras raras como peróxido, numa operação seqüencial à separação do tório.

Os peróxidos de terras raras também podem ser levados aos óxidos correspondentes por calcinação ou então, como para o tório, podem ser dissolvidos com ácidos para a preparação dos correspondentes sais.

Ainda sobre as terras raras foi observado que, de acordo com as análises, aqui apresentadas, elas não seguem a lei de distribuição original, vinda da 
monazita. Deve ter havido algum fracionamento, já no início da concentração do tório ainda na fábrica Nuclemon.

Com exceção do cério e do neodímio, as demais, terras raras não foram analisadas. Este trabalho deverá ser feito a-posteriori, usando o concentrado de peróxido de terras raras obtido segundo o procedimento descrito nesta dissertação.

O RETOTER usado para esta dissertação contém pequenos teores de urânio. O nitrato de uranilo também pode ser levado ao peróxido por adição de água oxigenada. $\mathrm{O}$ pH de precipitação do peróxido de urânio está em 2,5. Assim, o peróxido de urânio acompanha o tório ${ }^{[37]}$.

O estudo de separação destes pequenos teores de urânio será feito posteriormente. O objetivo mais urgente era a separação tório - terras raras urânio, reaproveitados do RETOTER. As demais impurezas deste resíduo ficam nos filtrados dos peróxidos.

O ${ }^{228} \mathrm{Ra}$ foi separado seletivamente nas frações do peróxido de tório e do carbonato de terras raras. O porcentual maior pode ser observado no sulfato de bário(rádio). $\mathrm{O}{ }^{228} \mathrm{Ra}$ observado na fração peróxido de tório foi de $0,56 \%$, e o ${ }^{228} \mathrm{Ra}$ na fração de carbonato de terras raras foi de aproximadamente $1,2 \%$, ambos em relação à fração do sulfato de bário(rádio). $\mathrm{O}{ }^{228} \mathrm{Ra}$ quantificado tanto na fração do peróxido de tório, como na fração de carbonato de terras raras é muito baixo em relação ao que foi quantificado no sulfato de bário(rádio) confirmando que o ${ }^{228}$ Ra foi separado na sua fração.

As operações estabelecidas para a separação das frações seletivas foram efetivas sendo comprovada pela analise das frações por espectrometria gama. A espectrometria gama é uma técnica barata, bem estabelecida em rotina, embora exija o tempo de espera para a obtenção do equilíbrio radioativo.

Observou-se que as etapas de tratamento do RETOTER são simples de serem realizadas e uma vantagem é que são quase todas realizadas à 
temperatura ambiente. Com exceção da dissolução nítrica, que necessita de aquecimento à temperatura de $80^{\circ} \mathrm{C}$ e da precipitação do sulfato de bário(rádio). Portanto, tem-se uma grande economia no consumo de energia elétrica. Os reagentes químicos utilizados são relativamente baratos e facilmente encontrados no mercado.

Acredita-se que com a metodologia desenvolvida nesta dissertação foi possível alcançar êxito tanto na descontaminação da solução de RETOTER, assim como na separação de tório e terras raras.

Quanto ao estoque de RETOTER existente e armazenado no depósito de Salvaguardas justifica-se o estudo de um método que separe o rádio, o tório, e as terras raras para as suas devidas aplicações. Além disso, este material futuramente será transferido para outra instalação e, portanto é importante que se tenha um método de tratamento. O RETOTER é o produto final do processamento da matéria-prima sulfato de tório cristalizado, sendo assim estará encerrando um ciclo total de aproveitamento do material. Reaproveitar o resíduo é uma atitude sensata. 


\section{REFERÊNCIAS BIBLIOGRÁFICAS}

1. BRIL, K. J.; KRUMHOLZ, P. Produção de Óxidos de Tório Nuclearmente Puro. São Paulo, 1965 (IEA-PUB-115).

2. AMORIM, H. A. L. Tório, Terras Raras e Plutônio. São Paulo Ministério de Minas e Energia - CNEN, 1978.

3. COHEN, V.H. Determinação Simultânea de Actinídeos por Espectrometria de Fluorescência de Raios-X. 1990. Dissertação (Mestrado) - Instituto de Pesquisas Energéticas e Nucleares, São Paulo.

4. CAMARGO, I. M. C. Determinação da Concentração dos Isótopos Naturais de Urânio e Tório em Amostras de Água. 1994. Dissertação (Mestrado) - Instituto de Pesquisas Energéticas e Nucleares, São Paulo.

5. IKUTA, A. Tecnologia de Purificação de Concentrados de Tório e sua Transformação em Produtos de Pureza Nuclear. Estudo do Sistema Th $\left(\mathrm{NO}_{3}\right)_{4}-\mathrm{HNO}_{3}-\mathrm{NaNO}_{3}$ - TBP - VARSOL, 1977. Dissertação (Mestrado) - Escola Politécnica, USP, 1976. (IEA-PUB035).

6. ABRÃO, A, Química e Tecnologia das Terras-Raras. Série Tecnologia Mineral, v.66, CETEM/CNPq. Rio de Janeiro, 1994.

7. VASCONCELLOS, M. E. Resolução da Mistura Tório e Terras Raras por Precipitação Fracionada e Tecnologia de Troca lônica. 2001. Dissertação (Mestrado) - Instituto de Pesquisas Energéticas e Nucleares, São Paulo. 
8. CAMILO, R. L. Dados de Equilíbrio no Sistema $\operatorname{Th}\left(\mathrm{NO}_{3}\right)_{4}$ $\mathrm{UO}_{2}\left(\mathrm{NO}_{3}\right)_{2}$ TBP/VARSOL $-\mathrm{HNO}_{3}-\mathrm{H}_{2} \mathrm{O}$. Optimização das Variáveis para a Separação de $T^{232}$ - $U^{233}$. 1982. Dissertação (Mestrado) Instituto de Pesquisas Energéticas e Nucleares, São Paulo.

9. ABRÃO, A.; FREITAS; A. A.; AND CARVALHO, F. M, S.; Preparation of Highly Pure Thorium Nitrate Via Thorium Sulfate and Thorium Peroxide, J. Alloys Compd., v. 323-324, p. 53-56 (2001)

10. FReitas, A. A.; CARVAlho, F. M. S.; FERREIRA, J. C.; ABRÃO, A.; Transformação Via Peróxido de um Hidróxido Bruto de Tório em Nitrato para Camisas de Lampião. INAC 2002-VI ENAN International Nuclear Atlantic Conference, Rio de Janeiro, Brasil. Revista Brasileira de Pesquisa e Desenvolvimento Vol. 4 - nr. 3 Parte 2 - Setembro 2002, p.1606-1609.

11. G.L.JOHNSON.; M.J.KELLY; D.R.CUNEO, Reactions of Aqueous Thorium Nitrate Solutions with Hydrogen Peroxide .J. Inorg. Nucl. Chem., Volume 27, Issue 8, August 1965, Pages 1787 - 1791.

12. <http://www.mspc.eng.br/quim.1/quim1_090.asp> Acesso em: 18 maio 2007.

13. KIRBY, H.W. E SALUTSKY, M. L. The radiochemistry of Radium, NAS - NS 3057 (1964) p.(4, 8-14).

14. <http://www.tabelaperiodica.hpg.ig.com.br > Acesso em: 09 junho 2005.

15. BANDEIRA, L. F. M.; LOUREIRO F. E. L.; ARAUJO, R. V. V. Estudo da Lixiviação Nítrica de Concentrado Fosfático; UFRJ.

Disponível em: <http://www.cetem.gov.br/publicacao/CTs/CT2002-061-00.pdf>. Acesso em: 09 junho 2005. 
16. CARVAlHO, D. A.; ARAUJO, R. V. V.; LOUREIRO, F. E. L. Lixiviação Clorídrica de Concentrado Fosfático: Estudo de Caso; UFRJ: Disponível em: <http://www.cetem.gov.br/publicacao/CTs/CT2002-196-00.pdf>. Acesso em: 09 junho 2005.

17. <http://www.nautilus.fis.uc.pt/st/2.5/scenes-p/> Acesso em: 09 maio 2005.

18. MARTINS, T. S.; ISOLANI, P. C.; Terras raras: Aplicações Industriais e Biológicas - Instituto de Química, Universidade de São Paulo/SP - Quim. Nova, Vol. 28, No. 1, 111-117, 2005 - publicado na web em 5/11/04.

19. BRIL E CAMARGO, N. U. Sobre a Estabilização de Diluentes Orgânicos Usados no Processo de Extração de Tório e Urânio com Tributilfosfato. São Paulo, Orquima, Lab. Pesquisas, 1959.

20. MARTINS, E. A. J.; ABRÃO A., Reaproveitamento de Valores nos Efluentes Líquidos das Unidade-piloto de Urânio e Tório. 1990. Dissertação (Mestrado) - Instituto de Pesquisas Energéticas e Nucleares, São Paulo.

21. IKUTA, A. E COSTA, E. C. An Optimization Study of the Precipitation of Thorium Oxalate. São Paulo, Instituto de Energia Atômica, 1969 (IEA - Pub.183).

22. IKUTA, A. E COSTA, E.C. An Experimental Approach to the Opitimization of Solvente Extration Processes. In: Southwest Research Institute, San Antonio, Texas, 1970.

23. ZINI, J.; ABRÃO, A.; CARVALHO, F. M. S.; FREITAS, A. A; SCAPIN, M. A.; Estudo do Tratamento de Um Resíduo de Tório e Terras Raras por Cromatografia de Extração INAC 2005 - International Nuclear Atlantic Conference, Santos, SP - Brazil, August 28 to September 2, 2005. 
24. SENEDA J. A.; Separação e Recuperação de Chumbo-208 dos Resíduos de Tório e Terras Raras Gerados na Unidade Piloto de Purificação de Nitrato de Tório. 2006. Tese (Dotourado) - Instituto de Pesquisas Energéticas e Nucleares, São Paulo.

25. BRANDÃO, F. D.; HESPANHOL, E. C. B.; SHIGUEAKI, B.; MIRANDA, L. E. T.; ARAUJO, J. A.; Reaproveitamento do Tório Contido em Resíduos Provenientes da Usina de Purificação de Tório. São Paulo: 1992 (IPEN-PuBb-375) p.3, 1992.

26. Relatório Referente à Liberação dos Efluentes Radioativos Líquidos da Unidade Piloto de Purificação de Tório do Departamento de Radioproteção Ambiental/IPEN-SP, outubro de 1996.

27. CUNHA, K.M.A.D.; Contribuições ao Estudo da Exposição Ocupacional ao Tório no Brasil. 1997. Tese (Doutorado) - Universidade Federal do Rio de Janeiro, Rio de Janeiro.

28. SCAPIN, M. A. Aplicação da Difração e Fluorescência de Raios-X (WDXRF): Ensaios Argilominerais. 2003. Dissertação (Mestrado) - Instituto de Pesquisas Energéticas e Nucleares, São Paulo.

29. INSTITUTO DE PESQUISAS ENERGÉTICAS E NUCLEARES. Manual de Métodos Analíticos IPEN, Determinação da Concentração de Tório por Titulação Complexante. São Paulo, 1989 (IPEN - Procedimento - QI - 052).

30. INSTITUTO DE PESQUISAS ENERGÉTICAS E NUCLEARES. Manual de Métodos Analíticos IPEN, Determinação da Concentração Total de Terras Raras por Gravimetria. São Paulo, 1989 (IPEN - Procedimento - QI - 053). 
31. INSTITUTO DE PESQUISAS ENERGÉTICAS E NUCLEARES. Manual de Métodos Analíticos IPEN, Determinação de Impurezas em Urânio e seus Compostos. São Paulo, (IPEN - Procedimento QI - 001).

32. SANTOS, A. J. G.; Avaliação do Impacto Radiológico Ambiental do Fosfogesso Brasilerio e Lixiviação de ${ }^{226} \mathbf{R a} e^{210} \mathrm{~Pb}$. 2002. Tese (Dotourado) Instituto de Pesquisas Energéticas e Nucleares, São Paulo.

33. Dra. Christina Aparecida Leão Guedes de Oliveira comunicação pessoal, em junho de 2005.

34. TOMIDA, E. K.; ABRÃO, A.; Carrier-Free Separation of ${ }^{228}$ Th from $\mathrm{BaSO}_{4}\left({ }^{228} \mathrm{Ra}\right)$, Centro de Engenharia Química - Instituto de Energia Atômica, Radiochem. Radioanal. Letters, 29(3) 131-138(1977).

35. MOREIRA, S. R. D.; Determinação de ${ }^{210} \mathrm{~Pb}$ em Águas Minerais da Cidade de Águas da Prata. 1993. Dissertação (Mestrado) Instituto de Pesquisas Energéticas e Nucleares, São Paulo.

36. OlIVEIRA, J.; Determinação de ${ }^{226} R a$ e ${ }^{228} R a$ em Águas Minerais da Região de Águas da Prata 1993. Dissertação (Mestrado) - Instituto de Pesquisas Energéticas e Nucleares, São Paulo.

37. MODENESI, C. R.; ABRÃO, A.; Produção Experimental de Peróxido de Urânio e Seu Uso para Obtenção de $\mathrm{UO}_{2}$ Cerâmico. Anais Associação Brasileira de Química 33(1-4) 31-36,1982. 